\title{
Beachcombing and Coastal Settlement: The Long Migration from South Africa to Patagonia- The Greatest Journey Ever Made
}

\author{
Barry Wood \\ University of Houston
}

\begin{abstract}
Although studies of prehistoric human migration now run into the hundreds, a single, chronological narrative of the peopling of the planet has not yet been presented, Most studies have been produced by specialists of a region. The need for a specific migration narrative - highlighting a primary migration route - is desirable for a coherent big-history understanding of how prehistoric Homo sapiens peopled the planet. Assembling the existing research, we follow the primary migration route from South Africa to Patagonia - a coastal trek up the coast of Africa, along the shores of the Indian Ocean followed by a circum-oceanic trek around the entire Pacific Ocean., the whole journey, with settlements established along the way, occurring over a period of 60,000 up to 115,000 years. From South Africa, now recognized as the refuge of early Homo sapiens, migration can be traced through human fossils, cave occupations, camp and work sites, shell middens, animal remains, and tool remnants. To these, genetics has added the identification of genetic markers for more accurate route determination. This coastal migration route incorporates recent archeological reassessments that have confirmed (1) the "Southern Dispersal" route out of Africa to coastal South Asia; (2) a 10,000 to 15,000 thousand year "Beringian Standstill" during the last glacial maximum; and (3) a primary "Coastal Route" down the west coast of the Americas. From this primary coastal migration route, hundreds of rivers provide resource-rich entrances into continental interiors while ocean reaches beckoned to the adventurous, thus clarifying the earliest stages of the peopling of the Earth.
\end{abstract}

Correspondence | Barry Wood, barrywood1940@yahoo.com

Citation | Wood, B. (2019) Beachcombing and Coastal Settlement: The Long Migration from South Africa to Patagonia - The Greatest Journey Ever Made. Journal of Big History, III(4); 19 - 46.

DOI | https://doi.org/10.22339/jbh.v3i4.3422

The coastal route would be a sort of prehistoric superhighway, allowing a high degree of mobility without requiring complex adaptations to new environments that would be necessary on an inland route. . . because of the ease of movement afforded by the coast, the line of sandy highway circumnavigating the continents, this would allow relatively rapid migrations. No mountain ranges or great deserts to cross, no need to develop new toolkits or protective clothing, and no drastic fluctuations in food availability.

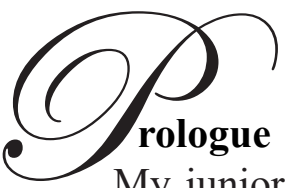

My junior high school world history textbook began with chapters on the Egyptians and Greeks, but in so doing, it left me puzzled. What had happened over tens of thousands or even millions of years since primitive ancestors of humans had roamed African jungles? In 1956 there were few clues to the prehistoric past of humans, but I had heard about a South African skull- the Taung skull, I learned much later-
- Spenser Wells, The Journey of Man (2002) found in 1924 by Raymond Dart that he had named Australopithecus africanus - defined as "the Man-ape of South Africa." This empty stretch of time in the prehistory of humans persisted for a long time, and my perusal of works like H. G. Wells' Outline of History (1920), revised up until the end of World War II, did not satisfy the question. The earliest historically precise date Wells could provide was $776 \mathrm{BCE}$, derived from a Greek text that listed the winners that year in 
the Olympic Games. Events of earlier times were narrated in the the Iliad, the Odyssey, the Old Testament, and the Epic of Gilgamesh, though one hardly felt like any of these could be regarded as factual history.

Through the decades after high school, I watched for details on the African origin story. In the quarter century after Dart's South African discovery, it was given little attention because of a general resistance to the idea of Africa as the homeland of Homo sapiens. There were several rivals that predated it. A skull found on the island of Java (1891-1892) known as Java Man pointed to an Asian origin, as did the discovery of ancient human remains in Zhoukoutien Cave near Peking, now Beijing (1923-1927), known as Peking Man, and predating both, the discovery of remains known as Neanderthal Man (1856) named for the Neander Valley in Germany where they were unearthed. The prevailing Eurocentric view of the early $20^{\text {th }}$ century was enhanced by the discovery in England of a carefully contrived hoax known as Piltdown Man (1912). Neglect of the African-origin theory continued until the Piltdown skull was exposed as an elaborate fabrication in 1953. Soon thereafter, Robert Ardrey's African Genesis (1961), which I read immediately following its publication, brought Dart's Taung skull into focus, clarified its importance, and explained the delay in recognizing its importance: "no fossil background for Dart's creature had ever been found in all Africa."

But Dart's claim (1925) that "the specimen . . . exhibits an extinct race of apes intermediate between living anthropoids and man" still proved too challenging for the European anthropological establishment, let alone the general public. A Eurocentric bias meant an African origin for modern humans was beyond imagining.

\section{Accumulating Evidence for an African Origin}

African Genesis marked the beginning of a new dawn for anthropological theory. The next quarter century turned up multiple verifications from East and Central Africa. The best known was Donald Johanson's

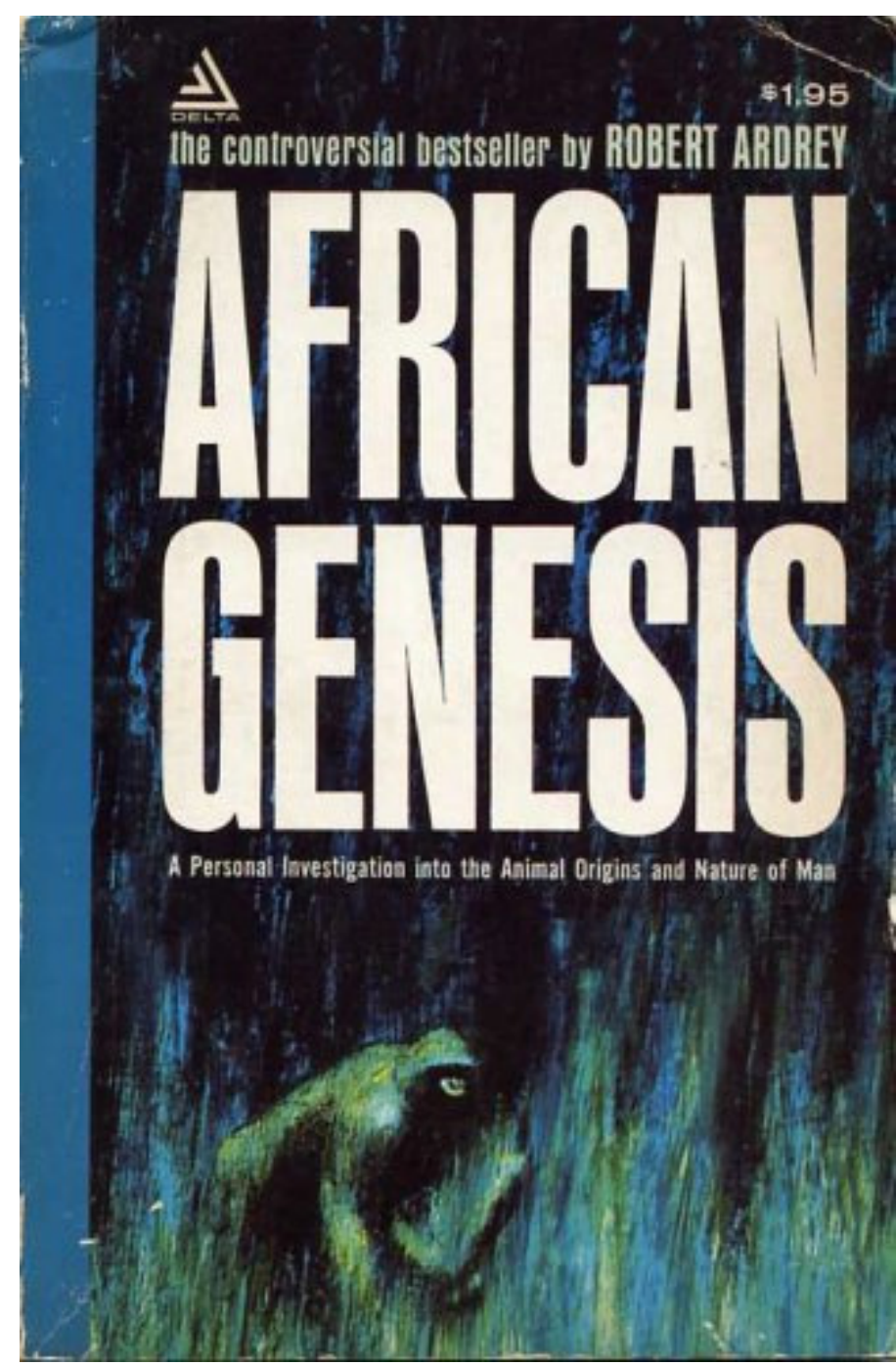

Fig. 1. Robert Ardrey's African Genesis (1961) provided the first full treatment of human origins in Africa. The book was a remarkable piece of hobby journalism from a playwright, Hollywood screen writer, and actor on the Broadway stage. Ardrey followed this book with another highly readable contribution in anthropology, The Territorial Imperative (1966). Image source: www.amazon.com.

1974 discovery at Hadar in Ethiopia of a 3.2 million year old hominin, Australopithecus africanus, more commonly known as "Lucy." Three years later, Mary Leaky uncovered three sets of $A$. africanus footprints at Laotoli in the Olduvai Gorge. These were made by two adults walking together step by step, perhaps 
holding hands, and a meandering child - the three providing a brief glimpse into prehistoric family life. The footprints were made in volcanic ash turned to rock dating to 3.7 million years of age. As Raichlen et al (2010) have noted, the Laotoli footprints are now recognized as our "earliest direct evidence of human-like bipedal biomechanics." There were other dramatic discoveries, of course, enough to remove all doubts concerning the prehistory of humans in Africa and to piece together a tentative prehistory of Homo sapiens.

A visual answer to my long standing high school question took shape when I opened my October 1988 issue of National Geographic where fragmentary glimpses coalesced in a map of "the peopling of the Earth" (Fig. 2). Its striking answer was captured in arrows out of Africa tracing human migrations to Australia, Asia, Europe, and eventually the Americas.

Dates in thousands of years at various points on the map-96,000 in South Africa, 50,000 in Australia, 33,000 in Europe, 12,000 in North America-plotted the progress of humans in their movement across a prehistoric landscape of six continents. Distinctions we recognize today had not yet been worked out: the map mixed much earlier migrations of Homo erectus with the much later migration of Homo sapiens; moreover, generalized arrows raised more questions. The arrow from Africa to Australia passed through Israel, crossed over the Himalayas, then leaped from land to water at Myanmar and followed a water route through the Strait of Malacca, with a final jump from the Indonesian island of Java to Australia. As Nicholas Wade (2006, 76) remarks of these early migration maps, "the arrows unavoidably give the impression that the emigrants were purposely traveling to these distant endpoints. . .. In fact, it's doubtful that they were on a journey at all." But movement through the Americas was equally schematic_-simplified to an arrow from Alaska through the center of Canada and the American Great Plains to Central and South America. Arrows traversing enormous spans of the Pacific Ocean raised questions of watercraft, especially since KonTiki (1948), Thor Heyerdahl's bestseller account of a Pacific Ocean crossing on a raft, had suggested Pacific colonization from South America, but Heyerdahl's theory did not fit the evidence and was absent from the National Geographic article. Firm evidence was limited to a scattering of excavation sites from which generalized migration routes were inferred, but details of prehistoric life in Africa or during their subsequent migration were missing.

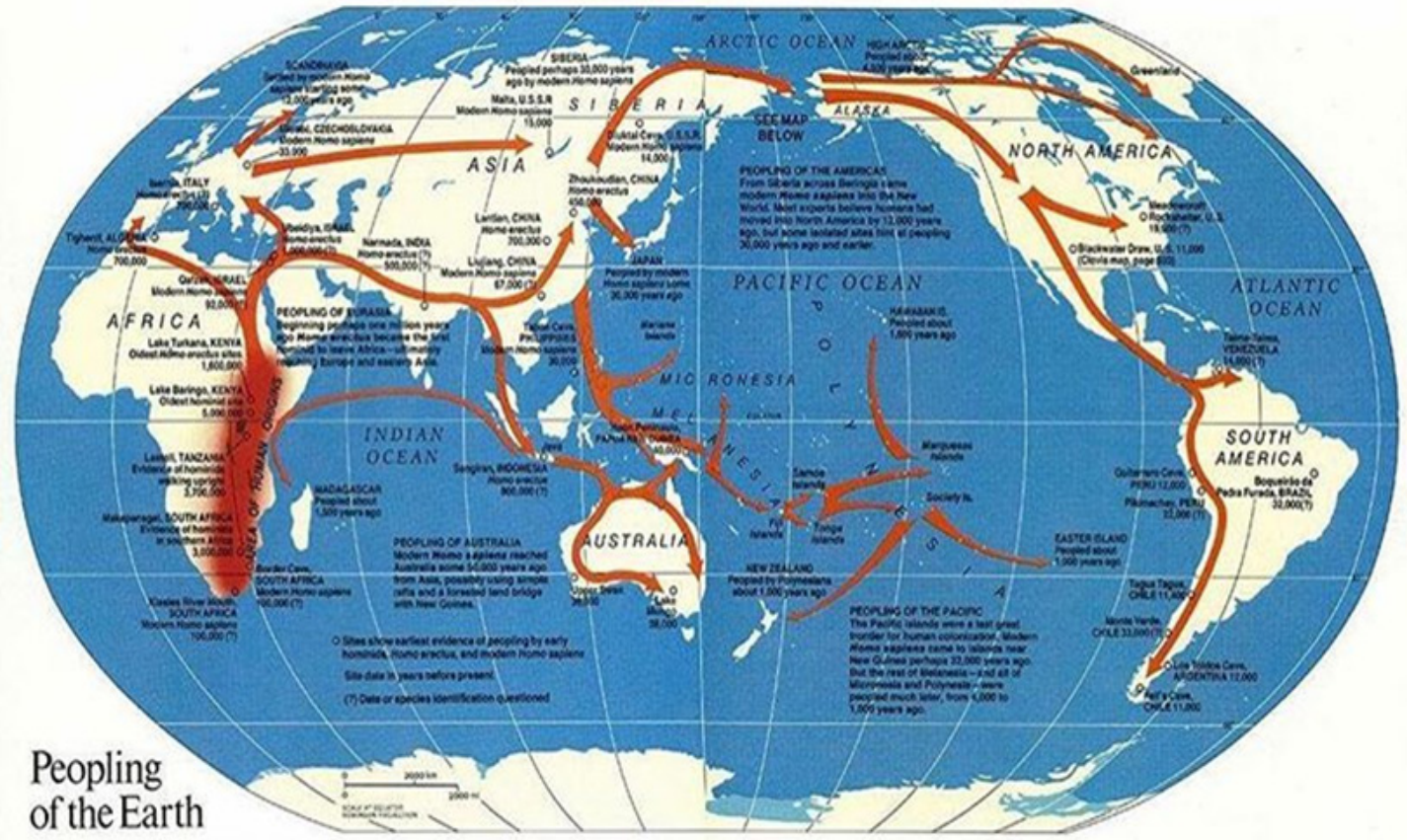

Fig. 2. An early map of prehistoric human migration from "The Peopling of the Earth" issue of National Geographic, October 1988. Note the generalized migration routes which are dependent on a limited number of fossil sites. Image source: www.natgeo.com. 
Since early in the millennium, Africa as the homeland of modern humans has been settled science with 80,000 BP an approximate date for their departure (Oppenheimer 2003). Dozens of books and thousands of articles over the past half century have followed discoveries of hominid fossils, cave occupations, stone age tools, and prehistoric worksites. Paleoclimatology has clarified regional occupation at different times and genetic analysis has established relationships between human populations across Africa and beyond. Much of this information remains unknown, though an African genesis for anatomically modern humans is solid enough to know that this is where the human journey began. As Armitage et al (2011) and others have detailed, the evidence is substantial and the primary coastal route out of Africa well established. Many details of this journey are piecemeal with evidence from multiple regions of every other habitable continent. The routes that humans followed in the peopling of the world have been refined, are generally understood, and can be guessed by connecting the dots-linking each archeological site to the next, though the vast interior regions of Africa, Asia, and Europe offer too many "nexts." The result is a complex web of possibilities, with many missing details inviting guesswork. Despite a continuing vagueness of detail, by the end of the century Africa had been identified as the indisputable "cradle of modern humans" (Lewin 1987a).

\section{The South African Incubation}

The ideal of a unified narrative, dependent on a clearly defined migration route is valuable and essential for a coherent big-history understanding of how prehistoric Homo sapiens spread around the world. As the Prologue to this paper indicates, this question has engaged my attention for more than six decades. The paper itself was suggested by the title of a book reviewed elsewhere in this issue of $J B H$, Trekking the Shore (2011), which treats "the shore" in separate essays on human use of marine resources at twenty separate locations but fails to assemble them into a coherent "trekking" narrative. The volume relies on evidence from widely separated locations and thus depends on discovery and excavation by specialists who are expert on specific regions.

In contrast, this paper singles out the primary migration route by assembling the existing research on the primary migration route from South Africa-a route up the coast of East Africa, along the shores of the Indian Ocean, followed by a circum-oceanic trek around the entire Pacific Ocean that ended in Patagonia. This narrative has emerged because terrestrial food sources vary from plentiful to non-existent whereas marine foods are the most reliable of environmental resources from the tropics to the coldest regions of the Arctic.

Of primary importance for this narrative is establishing the departure point of this migration. Most of the discoveries of prehistoric hominid fossils, with the except of the Taung skull, were unearthed in East Central Africa: Louis Leaky's 1.75 million year old Australopithecus find, and the discoveries already mentioned by Donald Johanson and Mary Leakey. By the early 1990s, the theory of an African origin was secure. But while very ancient fossils of earlier species had turned up in East Central Africa, Homo sapiens fossils from this region were rare, though they were evident elsewhere. A recent discovery on the Atlantic coast of Morocco (Hublin et al 2017) has revealed that anatomically modern humans had expanded far beyond the original discovery region of East Central Africa. When conditions were favorable, it appears that early modern humans had possibly occupied much of the continent. Another discovery emerged from the Morocco site: a divergence of Homo sapiens as a separate species appears to have occurred as early as 350,000 to 260,000 years ago, much earlier than the 200,000 years that has been long assumed as a beginning date.

After 200,000 BP, however, and for the next 75,000 years there is little evidence of a Homo sapiens presence in western, northern, or eastern Africa. Petit et al (1999) have shown that the period known as 
Glacial Marine Isotope Stage 6 (MIS6), dated from pollen and plankton remains in seafloor sediment cores as lasting from 195,000 to $125,000 \mathrm{BP}$, was one of the longest and coldest periods of the Quaternary. Under these conditions, as geophysicist Robert Walter et al (2000) have pointed out, lower rainfall shifts forested regions toward a savannah landscape, or even steppe if dry seasons are extended. Walter's region of interest was Eritrea on the African coast of the Red Sea, but his observations apply to the whole of East Africa. Throughout this period most of the continent could not provide supportive floral and faunal resources for human habitation. Some isolated refuges may have harbored small groups for a time until they moved or succumbed to extinction. Successful groups were those that gravitated toward the narrow edge of the savannah adjacent to coasts where they could exploit marine food sources.

Evidence comes from occupation sites and artifacts along the southern coast of Africa. As the Taung skull dating indicates, ancestral species were present in South Africa for more than a million years. Recently Schlebush, et al (2017) have drawn attention to the South African coastal region as a habitat of central importance in the narrative of modern human emergence where numerous caves show evidence of more congenial living conditions and extended human occupation. By the time Homo sapiens emerged 350,000 to $200,000 \mathrm{BP}$ they had acquired a pan-African gene pool of great diversity from earlier species over at least two or three million years. Surprisingly, though, the genome of modern humans outside Africa has a comparatively low genetic diversity, suggesting that the modern non-African human lineage was squeezed through a genetic bottleneck. A limited population - a regionally focused breeding group from which peripheral diversity had been snipped away by territorial concentration - appears to have formed the founding population of subsequent Homo sapiens outside Africa. Anthropologists and geneticists (Fagundes et al 2007; Gonder et al 2007; Benhar et al 2008) have described and dated this bottleneck within the Glacial Marine Isotope Stage 6, thus placing it within the period of the South African habitation.

The unique ecosystem of South Africa, specifically the Cape Floral Region (CFR), is the key to its importance. The CFR is one of the richest and most congenial environments where the major population of Homo sapiens dwelled throughout Marine Isotope Stage 6, thus providing an extended incubation for acquisition and development of survival skills both physical and cognitive. The region occupies an area roughly 200 by 400 kilometers for an official area of $78,555 \mathrm{~km}^{2}\left(31,000 \mathrm{ml}^{2}\right)$; it is one of two hotspot Floral Kingdoms on the planet, so rich in plant species that it is today one of the Global 200 priority ecosystem conservation regions, designated a UNESCO World Heritage Site in 2004. With valleys, hills, and mountainous variations in elevation, it includes three climate regions, thousands of floral species, and a rich array of shorebirds and mammals.

This ecosystem provided numerous edible roots, tubers, bulbs, and corms (geophytes); appropriately, anthropologist Curtis Marean (2012) has described it as "a coastal cornucopia." Important for our story are the numerous rock shelters and caves along the coast, some with spectacular views of the Indian Ocean. Here we find evidence of occupation extending to ancestral hominin species as well as occupation by Homo sapiens extending from 200,000 BP with access to diverse seafood resources. The total population of this region may have remained below 10,000; the range of population possibilities calculated by Fagundes et al (2007) indicates that population may have fallen as low as 600 , a marginal number for any species, which suggests Homo sapiens could well have gone the way of a dozen earlier extinct hominin species.

Despite climate and environmental confinement to the region, the evidence of survival strategy and cognitive advance from this population is rather remarkable. Nuno Bicho et al (2011, xix) have noted that "coastal food sources are rarely transported more than $10 \mathrm{~km}$ [6 miles] from the shore and most of the evidence [in South Africa] has accumulated within 


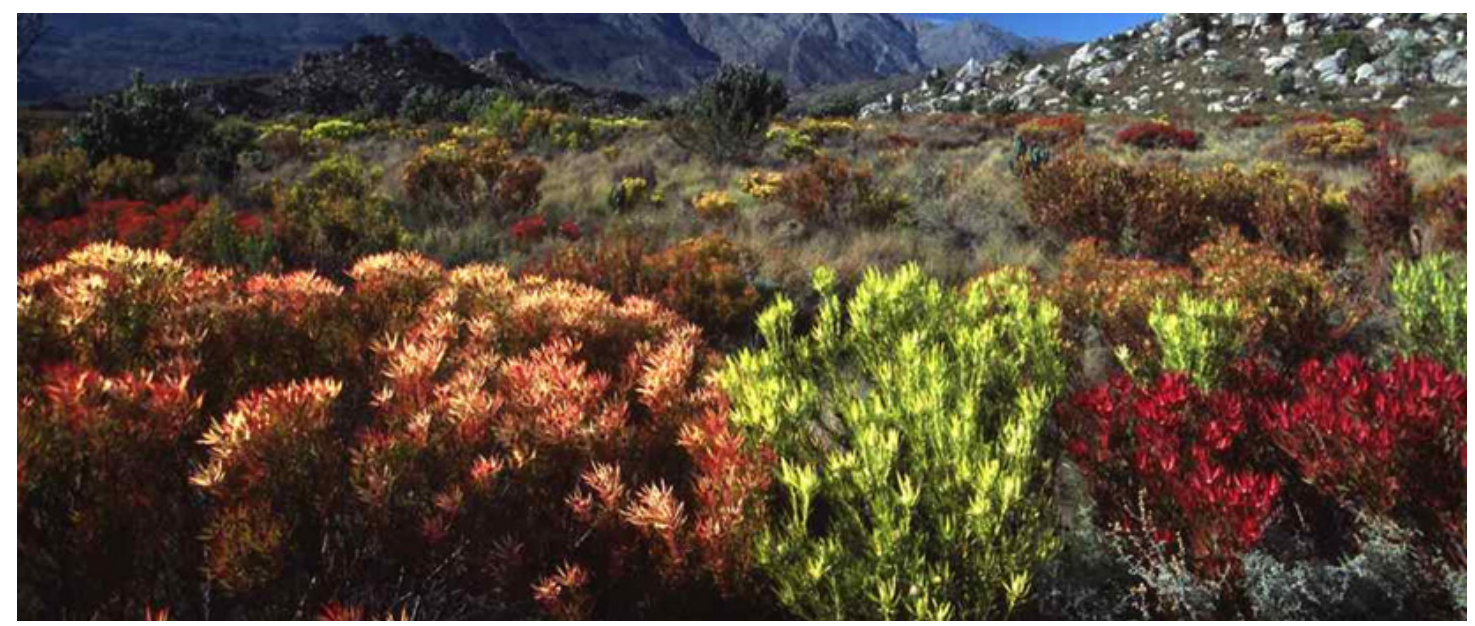

Fig. 3. The Cape Floral Region of South Africa, noted for exceptional temperate biodiversity, is home to 9000 species of plants, sixty percent of which are endemic to the region. The coast is populated with five tortoise species specific to the region, along with seals, seabirds, penguins, and antelope. Human occupation in more than twenty caves extends through the entire 200-thousand-year history of Homo sapiens. Image source: whc.unenesco.org.
When extensive cave art in Europe was discovered in Europe at Altamira and Lascaux, it was considered evidence for a leap in cognitive ability around 40,000 BP, perhaps stimulated by the challenges of the Ice Age, that accounted for the foundational skills of modern civilization and culture - and perhaps the dominance of Homo sapiens over Neanderthals that led
2-4 km." In the Cape Floral Region, more than two dozen caves or cave complexes within this range provide systematic records of human occupation, culture, technology, and harvesting of seafood. A complex mix of cultural achievements emerged here: various kinds of stone cutting tools, bone implements, and the beginnings of personal decoration in the form of pierced shells, obviously for stringing into beads. Tools have been found at inland sites such as Cooper's Cave (Berger 2003). Fragments of engraved ostrich egg water containers dating from 65,000 to 55,000 years ago have been found at Diepkloof Rock Shelter. Pierre-Jean Texier (2010) who made the discovery, notes that the engravings seem to be made for display, perhaps indicating a communal connection, and were hardy enough to serve as canteens while away from a water source. Brown et al (2009) have deciphered the technology that employed fire to harden rock for tool making at Pinnacle Point, a technology evident from 195,000 to $90,000 \mathrm{BP}$. These and other practical and decorative innovations may be considered proxies for an upsurge in Homo sapiens linguistic, symbolic, and cognitive competence. to their extinction around that time. This emphasis appears, too, in The Roots of Civilization (1972), Alexander Marshack's extensive analysis of engraved bones, and his concept of "cognitive archaeology" whereby ancient artifacts are examined as proxies for cognitive development. As rich and suggestive as these observations were, the artistic, decorative, and technological accomplishments in South Africa suggest that a leap in human cognition and imaginative skills occurred more than 100,000 years earlier.

Seafood harvesting by occupants of Klasies River Caves (Thackeray 1988) and Pinnacle Point cave 13B (Marean 2007, 2011) suggest a dietary explanation for this upsurge: nutritional anthropologists have argued that continual harvesting of seafood during Glacial Marine Isotope Stage 6 points to seafood and shellfish as providing fatty acids not produced by the human body that are nevertheless instrumental for brain development (Cunnane et al, 1993; Crawford et al. 1998; Broadhurst et al. 2002). Long-term harvesting of seafood over a period of at least 70,000 years may have provided the nutritional stimulus instrumental in the dramatic development of cognition that characterizes humans during subsequent migrations 
that required multiple adaptations as they moved on to people the planet.

Alongside recognition of South Africa as a nutritionally rich incubation region for early Homo sapiens, studies of mitochondrial DNA (mtDNA), a marker unique to female genealogy, have verified a South African departure for humans as they set out to explore the world (Lewin 1987b). Rebecca Cann et al (1987) have shown that the entire human family traced to an ancestral "lucky mother" (popularized as "Mitochondrial Eve") who lived somewhere in sub-Saharan Africa. Recent calibration of ancient mitochondrial genomes by $\mathrm{Fu}$ et al (2013) suggest her date as around 160,000 BP. Within her line, Haplogroup LI/L0 successively gave rise to L2 and L3 around 80,000 BP, all "rooted deeply in subSaharan Africa with derivative branches outside" (Oppenheimer 2012). Atkinson et al. (2008, 2009) identify the Horn of Africa as the later origination point for the L3 haplotype, the source of the derived $\mathrm{M}$ and $\mathrm{N}$ genetic branches found in all non-Africans: Carbon dating indicates $\mathrm{M}$ and $\mathrm{N}$ originated between 69,000 and 50,000 BP. Numerous lines of inference verify this range of dates.

\section{Trekking Out of Africa}

A warming climate that began as Glacial Marine Isotope Stage 6 came to an end undoubtedly opened a path for movement of humans north from South Africa. Possible departure points from long-occupied caves stretching along more than $400 \mathrm{~km}(240 \mathrm{~m})$ of South African coastline would lead logically to numerous inland migration routes. However, the barrens of the Sahara desert would curtail or redirect some, though a route through the lake district of the north-running Rift Valley would provide an unobstructed passage to the north. Here, too, as Broadhurst (1998) has shown, Rift Valley lake fish and shell fish would provide similar nutritional benefits for cognitive development as marine seafood on the South African coast. Passage to the Nile River Valley would follow, leading ultimately to the coast of the Mediterranean.
The earliest movement of Homo sapiens out of Africa appears to have occurred from the Nile Valley, perhaps from the river delta. Dated fossil remains in Israel show that a small group from what is now northern Egypt headed northeast, but evidently advanced no farther than Skhul Cave on the slopes of Mount Carmel (Wells 2006, 116-117). Evidence of occupancy here and at Qafzeh dates from 110,000 BP. Steven Olson $(2002,75)$ maps a probable route across Sinai and north into Israel that suggests the Nile Valley as the most likely approach from the south. However, evidence of this early migration extends no farther than Israel. The size of this group cannot be determined. It was evidently numerous enough to leave a record over several millennia, but it declined, eventually becoming too small to sustain itself and had gone extinct by 70,000 BP and thus represents a backwater migration of little interest for the peopling of the world.

More than a hundred millennia of South African coastal living with a sustaining diet of seafood provides an explanation for human occupation long after some migrating groups left. However, adventuring should never be forgotten: unforced migration northward on the warmer east coast of the continent was virtually inevitable. Many years ago, Carl O. Sauer (1962) suggested that African seashores would provide the best environment for primitive humans - free of the vagaries of inland climate variations and rich in seafood resources. Spenser Wells, author of The Journey of Man (2002) and narrator of the related video, made the case for coastal migration: "The coastal route would be a sort of prehistoric superhighway, allowing a high degree of mobility without requiring complex adaptations to new environments that would be necessary on an inland route." While this was written from an understanding of coastal Africa, it applies to regions far beyond: "because of the ease of movement afforded by the coast, the line of sandy highway circumnavigating the continents, this would allow relatively rapid migrations. No mountain ranges or great deserts to cross, no need to develop new toolkits 
or protective clothing, and no drastic fluctuations in food availability" (Wells 2002, 69).

Conceivably a number of migratory groups may have followed the east coast of Africa with continual access to seafood encouraging short term settlement along the way. Such migrations would rely on experience from millennia of seafood harvesting on the southern cape. Despite the ease of this coastal "superhighway," progress might well have been unhurried with the establishment of a string of temporary coastal settlements, though this remains conjecture without specific material evidence. It is unlikely that coastal migrants would have entirely foregone floral foods and geophytes available within a few kilometers of the coast, but the abundance and reliability of seafood resources would favor beachcombing and some semipermanent coastal settlement. This coastal route would be limited to a narrow corridor defined by these alternate sources of food. Despite this limitation, traces of migration are still unlikely and in fact have escaped discovery; as Nuno Bicho et al. (2011, xv) point out, ancient shorelines have been inundated by rising seas brought on by post-glacial climate warming. Evidence in the form of tools, firepits, or middens may have existed on prehistoric beaches, but they are now as much as 100 meters underwater.

While material evidence of east coast African migration is lacking, recent genetic evidence has surfaced. In a survey of foragers, farmers, and herdsmen from South Africa, Malawi, and Kenya who lived between 400 and 3,100 years ago, Pontus Skoglund et al (2017) have turned up evidence of a very ancient, "hitherto unknown" pre-agricultural cluster of "hunter-gatherer populations stretching from Ethiopia to South Africa." David Reich, one of the investigators of the Skoglund study, refers to them as a "ghost population" of foragers that once dominated the east coast of sub-Saharan Africa, referring to them as "East African Foragers" (Reich 2018, 221). The study establishes that they show closer relationship to nonAfricans than to any population group within Africa. This ghost population, which was itself a complex mix of forager groups, may well be (or may be related to) the East African migrant foragers who found their way out of the South African Floral Region and whose descendants eventually migrated out of Africa.

An east African coastal route is evidenced beyond the Horn of Africa where early modern humans crossed the span of water between Africa and the Arabian peninsula at Bab-el Mandab, the "Gate of Grief." These migrants carried the deeply rooted femalebearer mitochondrial DNA (mtDNA) and malebearer Y-Chromosome ancestry along with a genetic marker that defined a unique haplogroup, in this case Haplogroup M (Wells 2006, 180-182). This marker maps out Homo sapiens beachcombing and coastal settlement beyond Africa-across southern Arabia, Oman, and the United Arab Emirates, South Asia into Pakistan, and northern India (Wells 2006, 180-182). The evidence indicates that the environment on the southern Arabian coast was more congenial than now, making possible progress that took modern humans to South Asia, Australia, and the coast of China.

While this Red Sea crossing could be reached from the inland Rift Valley of Africa - and may well have included a contingent of Rift Valley migrantsit is also the logical termination of an East African coastal route. Vincent Macaulay et al (2005) has characterized the crossing to Arabia as a "single, rapid coastal settlement of Asia," which we might guess corresponded to a favorable water level, a congenial climate event, or even a particularly enthusiastic group of adventurous leaders. However it was motivated, those who made the crossing appear to have been a coherent group of similar genetic makeup that carried only a portion of the genetic richness of the African population left behind. The constraints of this portion provide a way to guess how many migrants made the crossing: As reported by Nicholas Wade (1997), University of Maryland anthropologist Sarah Tishkoff estimates a group if 200 to 500 migrants, but Wade subsequently suggested as few as $150(2006,81)$.

Until recently, this crossing has been placed between 70,000 and 60,000 BP, but Armitage et al. 
(2011) suggest that migration across Southern Arabia may have occurred during the final millennia of Marine Isotope Stage 6 (MIS 6), 130,000 to 125,000 BP. During this glacial maximum, sea level was lowest and the width of the strait at Bab-el Mandab was at its narrowest, allowing for movement of a substantial population evidently never in danger of extinction. This earlier date is supported by stone tools from river beds in the Dhofar Mountains of southern Oman (Groucutt 2018) dating to more than 100,000 BP (Underwood 2011), illustrating a microlithic blade toolkit previously known only in Sudan. J. I. Rose (2007) has colorfully referred to this as "a trail of stone bread crumbs" from Sudan to Arabia. Precise dating for the earliest or latest departure from Africa has yet to be determined, but archeological and genetic evidence indicates this migration across Arabia and on to South Asian coasts was primary, as opposed to a northern departure through Sinai.

Wade $(2006,75)$ provides a map clearly marking the coastal route from Africa to Australia, but this route, now known as the Southern Dispersal Route, turns northward in the Indonesian islands and continues up the coast of East Asia to Siberia (Figure 4), and on to the Americas.

Higher sea level today along the coasts of Yemen, Oman, and the United Arab Emirates obscures coastal conditions at the end of Marine Isotope Stage 6 and early MIS 5; as Faure et al. (2002) point out, when sea level is lower, freshwater springs appear on emergent continental shelves - a result of a steepened downhill gradient from inland aquifers-providing a ready source of water for coastal migrants. An interesting segment on the video series, The Incredible Human Journey (Roberts 2009), has Alice Roberts with J. I. Rose boating off the southern coast of Arabia with Rose explaining the availability of fresh water from springs now submerged by sea-level rise. Regions of coastal vegetation associated with such springs along the southern margin of Arabia made for an easy transit to southeast Arabia where excavations at Jebel Faya in the United Arab Emirates indicate possible occupation by $130,000 \mathrm{BP}$.

Arrival at the mouths of the Tigris and Euphrates Rivers, which empty into the Persian Gulf, may well have presented a momentous choice, for these were the first major sources of fresh water from the interior

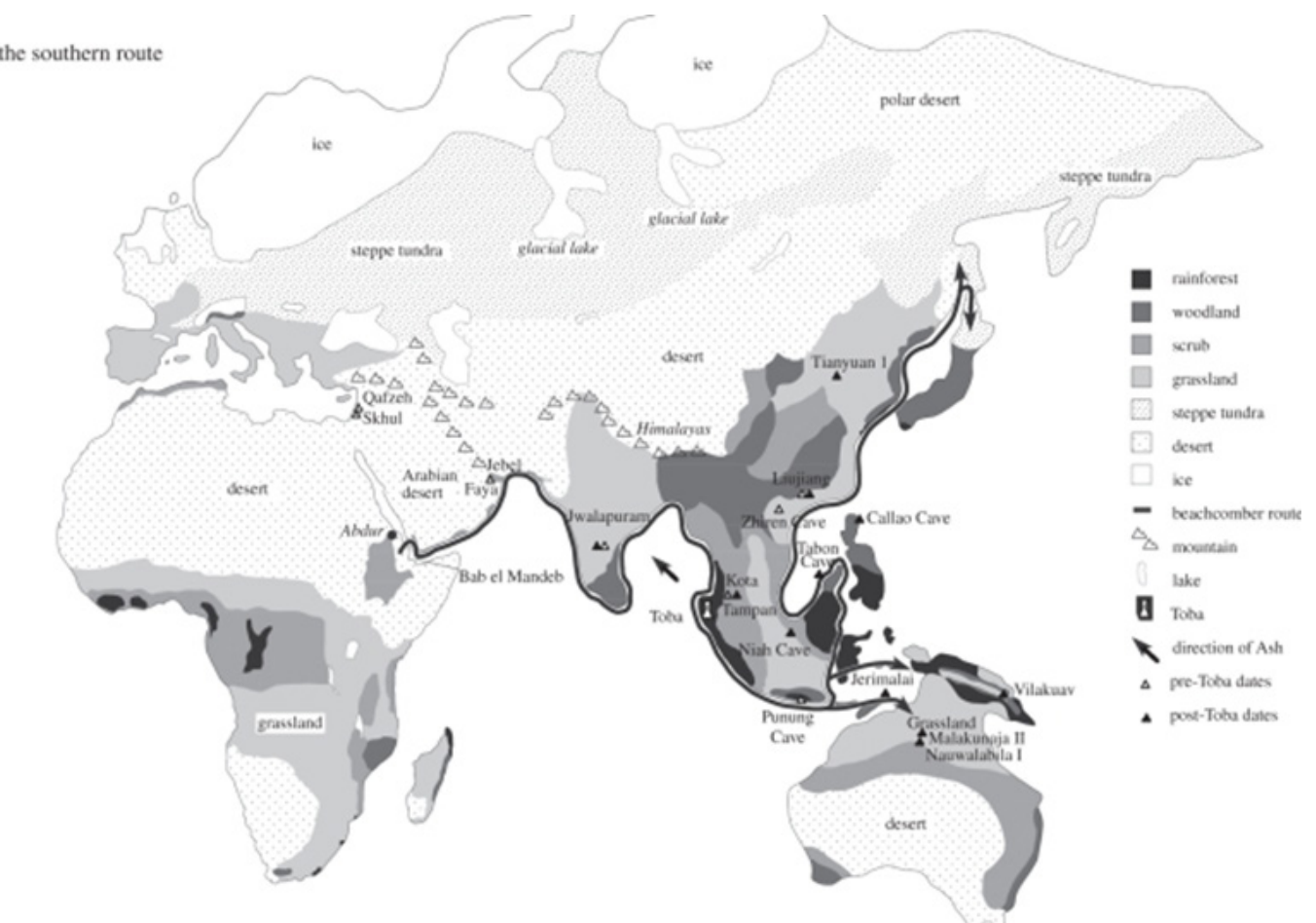

Figure 4. The crossing of the Red Sea from Africa to Arabia at Bab el Mandab marks the beginning of what is now called the Southern Dispersal route. The resulting coastal route follows the vast circuit of South Asian beaches on the Indian Ocean through India and Indonesia, then heads north from Indonesia, to the Philippines, China, Taiwan, Korea, Japan, and the Pacific coast to Siberia. Oppenheimer (2012) calls it the "beachcomber route." Image source: www. royalsocietypublishing.org. 
encountered by Southern Dispersal migrants. We will return to this later, noting here that this may have been a primary decision point where some migrants chose inland riverine rather than coastal migration, eventually becoming the founding population of the Asian interior and Europe.

The evidence from South Asia indicates that coastal trekking continued, probably along now submerged beaches of what are now Kuwait, Iraq, Iran, and Pakistan to Southern India. The western coast of India is short on material evidence. Here, as with the eastern coast of Africa, sea level 100 to 110 meters (300 to 400 feet) below the present level means prehistoric beaches are now submerged - in some cases along the west coast of India as much as $200 \mathrm{~km}$ (120 miles) offshore. The actual beaches followed by migrants harvesting seafood are thus now underwater with evidence of temporary settlements and middens washed away by rising tides. However, riverine migration points to the rich South India archeological site at Jwalapuram, inland on the Krishna River. Here microblade stone tools analogous to African predecessors extend the "trail of stone bread crumbs" that began in the Sudan. Indian sites provide evidence for dating: arrival of Homo sapiens at this subcontinent India site occurred after a now-reliably dated geological event. At 74,000 BP, the Mount Toba volcano in northern Sumatra erupted in what is now recognized as the most violent volcanic event of the Pleistocene Era. Remnants are evident all across Southeast Asia and India thousands of miles away. As Petraglia et al (2007) have documented, microblade lithic technology is evident at Jwalapuram shortly after the Toba event.

This extended inland settlement at Jwalapuram points to a feature of migration routes deriving from human behavior. People naturally fall into separate groups: contented settlers and adventurous explorers. Many years ago, anthropologists R. B. Lee and I. DeVore (1968, 245-249) worked out a mean size for a hunting-and-foraging band as around thirty individuals, which they called a "magic number" for population maintenance and cooperative sharing. In a resource-rich coastal environment, a group of thirty or more could subsist indefinitely at a convenient location near fresh water. But the rich marine resources and nutritional benefits of a coastal environment would soon lead to population increase, pushing population within a few years to forty, or perhaps fifty within a generation. Such increase would thus provide a motivation for group separation. Contented settlers might remain behind while adventurous explorers would push on, and some might choose a riverine route inland. Thus, as Wade writes, "in a century-five generations - a hunter-gatherer society might spread over a considerable distance ... [T] hose long distance migrations ... . were not made by a single group on a long trek, but were the slow expansion of human populations who took a generation to travel each leg of the journey. ... The world would thus fill up in a rather orderly way" (2006, 77-78). Over many generations, the settlers would develop localized genetic markers while adventurers would develop new markers that can be traced through later settlements along extended migration routes. Genetic mutations thus provide a permanent "memory" of human movement that can be discovered by DNA analysis of long-established indigenous people.

\section{Coastal Migration Beyond India}

Somewhere east of India, a single coastal route appears to have bifurcated into two. One led southward across the exposed bed of the Bay of Bengal to the Andaman Islands, then island hopped to the Nicobar Islands, Sumatra, and Island Southeast Asia. The efficacy of this route has come clear from genetic analysis of Andaman Islanders, a relict population that has occupied the archipelago for millennia (Thangaraj et al. 2003, 2005). The other followed the coast of Bangladesh, Myanmar, Thailand, and the Malay Peninsula to Island Indonesia where conceivably separate populations eventually melded. The whole complex story of migration in Island Southeast Asia is told in a revised presentation by Peter Bellwood (2017). 
Coastal migration in Southeast Asia was much more complex and ultimately more challenging than coastal trekking in Africa or South Asia, which feature fewer offshore islands. Initially, Southeast Asia was more peninsular than insular: lowered sea level turned sea bottom between Borneo, Java, Malaysia, and Sumatra into a linking lowland (called Sunda), a mixture of wetland and mangrove forest that no longer exists; numerous lands once joined are now separated. At the same time, much of present day Indonesia east of Borneo remained insular, which presented a water-crossing challenge for further movement. An oceanic barrier separated Borneo from Sulawesi and New Guinea, preventing animal migration-evident in the biological dividing line noted by Alfred Russell Wallace (the Wallace Line). This ocean divide isolated New Guinea and regions south and thus confined Australian fauna to a distinctive evolutionary path. But what separated animals did not prevent more enterprising humans from eventually making the crossing.

For two decades skeletons from the Lake Mungo site in New South Wales have provided 42.000 BP as benchmark date for the arrival of modern humans in Australia (Thorne 1999). At Madjedbebe, however, a rock shelter in Northern Australia, a series of progressively more refined excavations (1973, 1989, 2012, 2015) have turned up silcrete flakes, ground ochre, a grind-stone, and more than 12,000 stone artefacts. Advanced dating methods have yielded a much earlier age of 65,000 BP (Clarkson 2017) - a date which defines a minimum for departure from Africa and a narrow arrival window between 65,000 and 74,000 for arrival in India and regions in the vicinity of the Toba eruption.

Today, Southeast Asia is a land of islands: the Andaman-Nicobar archipelagos have 572, Malaysia has 878, Indonesia 18,307, Philippines 7,641, and despite the impression that Australia consists of one large island, there are 8,222 within its maritime borders. This astonishing total of more than 35,000 islands constitutes a ratio difference of coast to land such that beachcombing dominated food gathering, and more recent migration has almost always been coastal.

We recall that migrants from Africa crossed to Arabia bearing the $\mathrm{M}$ genetic marker. One variant, M 168, arose in northeast Africa, traveled across the Gate of Grief to Arabia, and eventually became the ancestor of inland migrants to the north in Eurasia (Wells 2002, 73). Then, somewhere along the coastal route of South Asia, probably after 75,000 B.P., an individual was born with another variant, giving rise to $M$ 130. The travels of M and M 130 form the plot of a coastal narrative tracing arrivals of the earliest population: M 130 increases from 5\% among the Adi and Negritos of India and the Andaman Islands, 10\% of the Orang asli (Original people) in Malaysia, $15 \%$ or original tribes in New Guinea, and 60\% among the Australian Aborigines. M 1 is found in 20 percent of mitochondrial types in India and nearly 100 percent in Australia (Wells 3002, 72-74). Following the challenges of water crossing from Borneo to New Guinea, migration southward to Australia presented few challenges. Lowered sea level had exposed a considerable expanse of seafloor - another prehistoric geographical area now known as Sahul. Seacoast migration down its western beaches would have led to north central Australia to the region of the Madjedbebe rock shelter near the coast (Clarkson 2017) already mentioned.

Dates now well attested provide a chronology for the Southern Dispersal narrative or Oppenheimer's Beachcomber Route: a departure from Africa between 120,000 and $80,000 \mathrm{BP}$, presence in India around $74,000 \mathrm{BP}$, arrival in Australia by $65,000 \mathrm{BP}$. With the subsequent arrival of the aboriginal Palawa in Tasmania approximately 40,000 BP, a coastal trek of thirty to eighty thousand years had reached a migratory end of the world. Meanwhile, a longer coastline remained to be discovered - a route north that would lead human adventurers on a still longer migration, ultimately to the most remote lands end in the greatest journey every made. 


\section{Trekking East Asian Beaches}

Migration north along the coast of China is almost a certainty given the distribution of genetic markers along the East Asian coast. Capelli et al (2001) have shown that Y-chromosome DNA Haplogroup O3M122 ("M" showing continuity with the coastal route out of Africa) is found among Chinese, Filipinos, Vietnamese, Taiwanese, and Koreans; additionally, Haplogroup 01a-M119 provides a further link between Filipinos and Taiwanese. Chang et al (2002) have shown that other genetic markers are common among Thais, Chinese, Indonesians, and Filipinos. It seems clear that some migrants from the Southern Dispersal route moved inland from Thailand across Laos, to Vietnam and Southern China where various inland settlement sites attest to Homo sapiens' presence (Olsen et al. 1992). But the southern branch of migrants who moved through the Malay Peninsula across Sunda to Borneo eventually brought Island Southeast Asia markers by a roundabout route to coastal East Asia. Tracking the migration route of coastal markers and haplogroups is difficult, however, because a shallow continental shelf off the coast of China means that temporary settlements, prehistoric worksites, and marine resource middens are now many miles offshore, inundated and destroyed by rising waters.

Offshore islands and archipelagos, however, are proxies for coastal continuity. The island of Palawan which runs diagonally for 280 miles between Borneo to the southwest and Mindanao on the northeast is a case in point. During the movement of Homo sapiens into Island Southeast Asia when sea level was lower, Palawan was connected to Borneo, providing a migration route that is verified by the 1962 discovery of human remains and extensive toolmaking worksites of the Tabon Cave complex dating to 47,000 BP. For more than half a century, Palawan has been celebrated as the Cradle of Philippine Civilization. Despite intervening ocean between Palawan and Mindanao, Palawan is the logical launching point for migration into the Philippines which was at that time a single landmass stretching north-south for 1500 kilometers (1100 miles). Subsequent sea level rise has now resolved this into an archipelago of 7,641 islands. More recently, Henderson et al (2007) have reported the 2007 discovery of a Homo sapiens foot bone at Callao Caves at the northern extremity of the Philippines that has superseded the Tabon Cave discoveries, pushing Homo sapiens occupation back to 67,700 BP.

The most dramatic effect of sea level as much as 120 meters (400 feet) lower than today was exposure of the entire seabed of the Taiwan Strait. At a distance of 130 kilometers $(100+$ miles $)$, present-day Taiwan is out of sight from mainland China, but during glacial times the exposed seabed formed a convenient land bridge across which faunal species and coastal Homo sapiens could traverse. In 1972, human fossils were discovered in the Zuozhen District on the northeast coast of Taiwan, including cranial fragments and a molar. Scientific advances have allowed for a dating of "Zuozhen Man" between 20,000 and 30,000 years BP (Liu 2009). Access to Japan from the mainland was also relatively easy from Korea at the southern end or Siberia to the north, particularly when lowered sea level reduced distances from the mainland. Fossils from three caves in Japan-Yamashita, Sakitari, and Shiraho-Saonetabaru-have yielded to Carbon 14 analysis with concordant dates of 32,000 to 27,000 BP (Matsu'ura 1999, Nakagawa 2010, Shinoda 2017), while an extensive dated killsite of prehistoric elephants--part of worldwide megafauna hunting that appears to have led to extinction-provides evidence of human presence as early as 40,000 BP.

\section{From Siberia to the Americas}

Today we know that modern humans had reached southern Siberia by 40,000 BP. One obvious route would follow from South Asian coastal separation, with riverine migrants from the Tigress-Euphrates Rivers pushing northward through the Black SeaCaspian gap to Central Asia. All such summaries of migration routes must be qualified by remembering that movement may have averaged no more than a 
few feet per year and would have required numerous adaptations to new environments, climate variations, and a gradual shift away from floral toward faunal food sources. But evidence along the way testifies to their acquisition of effective survival skills, including the remarkable mammoth bone shelters found in Ukraine in the valleys of the Don and DNiepr Rivers (Iakovleva and Djindjian 2005). Their expansion to the frigid expanse a few hundred miles from Ice Age glaciers may have taken as much as 20,000 to 30,000 years and thousands of generations.

Additional technological invention made survival in the coldest regions of the planet possible. Foremost is a hunting toolkit - spears and butchering blades; however caches of bone needles dating to $35,000 \mathrm{BP}$ found across northern Eurasia testify to the mastery of sewing and the fashioning of skin-tight clothing needed for survival in Arctic climates, making the needle one of humanity's transformative inventions.

Additional technological invention occurred around the time of the last glacial maximum, 25,000 BP, with the appearance of a microblade technology in the Altai and Lake Baikal regions (Goebel 2002; Kuzman et al, 2007)_first bifaces then microblades useful for survival in Arctic regions where big game hunting was the primary source of food. A similar sequence of microblade technology is evident a few millennia later in Japan and the Ushki Lake site in the Kamchatka Peninsula (Goebel et al, 2010). Along the edge of glaciers in Siberia, there appears to have been east-west movement, possibility because such populations were dependent on migrating herds of caribou and other large game. Theodore Shurr (2015) cites genetic evidence for population expansion from the Altai-Sayan region eastward toward Beringia around 25,000 BP carrying genetic markers that show up in later Amerindian populations. These migrants from west-central Siberia contributed a distinctive Y Chromosome marker, M242, that had separated at least 20,000 years earlier somewhere along the South Asian coastal route. Other microblade-equipped migrants moving north of Japan through the region of the Kamchatka Peninsula carried M13O, the defining genetic marker brought from the Horn of Africa, across the Gate of Grief, along the coast of South Asia, and up the coast of East Asia. Coming together in the Kamchatka region of northwest Siberia, these markers became the distinctive genetic components of migrants to the Americas.

Popular interest in the origin of First Nations Canadians, Native Americans, and archaic precursors of Central American civilizations dates to Thomas Canby's National Geographic article, "The Search for the First Americans" (September 1979) which followed his year spent with archeologists searching and excavating North and South American sites. Articulate in its treatment of migration, cautious with dates, informative on the development of agriculture in Mexico, and well-illustrated, the article provided an overview of then current knowledge still readable today.

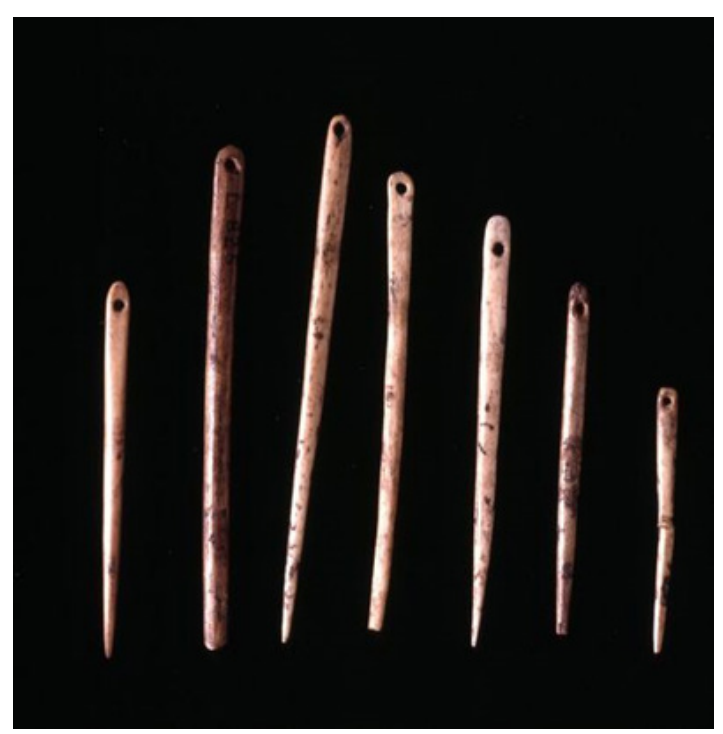

Figure 5. Bone needles made from the dense foreleg bones of horses or other hooved mammals display acquired skills of carving, smoothing and drilling. Caches of bone needles carbon dated to c. 35,000 BP have been found at several north European and Asian locations. Traveling, hunting, and dwelling in Arctic regions depended on the ability to fashion skin-tight clothing-shirts, pants, parkas, boots, and gloves. Image Source: Gilda Lyons. www.gildalyons. com. 
The Kamchatka Peninsula marked the beginning of an expansive region that extended from northeast Siberia to Alaska, including exposed seafloor extending north into the Arctic Ocean and south into the Pacific to the Aleutian Islands. It existed because so much water (70 million cubic miles) was tied up in continental ice during the Last Glacial Maximum that sea level was 100 to 120 meters (320 to 400 feet) lower than today. Typically referred to as a "land bridge" between Alaska and North America, this region is now called Beringia (Fig. 8), the name given to it by the Swedish geographer Eric Hulten (1937). This ecologically unified region stretched 1,000 miles east to west and 600 miles from north to south - all in all 620,000 square miles, greater than the combined area of Texas, New Mexico, Arizona, and Nevada. This vast region was the vestibule across which Asian travelers reached the Americas.

Given how recently we understood the movements of people in prehistoric times, it comes as a surprise that the first speculation about human migration from Asia was published in 1797 by Thomas Jefferson (1954, 100-101): "[G]reat question has arisen from

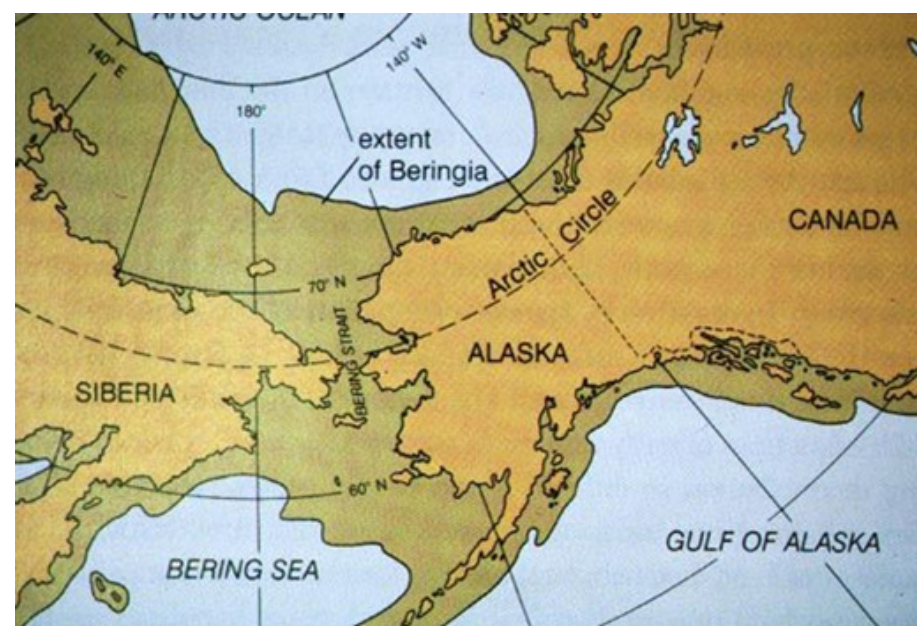

Figure 6. Beringia is the geographical name for the "land bridge" between Siberia and Alaska. With sea level 100 to 120 meters lower than today, extensive regions of continental shelf were above sea level, rich in flora and fauna, and thus a suitable habitat for prehistoric Homo sapiens who settled here for 10,000 to 15,000 years, a period known as the Beringia Standstill. Image source: www.pinterest.com. whence came those aboriginal inhabitants of America? ... [T] he late discoveries of Captain Cook, coasting from Kamchatka to California, have proved that, if the two continents of Asia and America be separated at all, it is only by a narrow straight. So that from this side also, inhabitants may have passed into America." Jefferson made this guess because of "the resemblance between the Indians of America and the inhabitants of Asia." The evidence today is a version of Jefferson's casual observation: the resemblance of genes between the Indians of America and the inhabitants of Asia. The story is more complex, of course, but Jefferson should not be dismissed as simply hazarding a lucky guess.

The evidence - not only a toolkit that included sewing needles and microblade technology but also traceable genetic markers - suggests that by 30,000 BP some groups had reached Beringia. Evidence for Homo sapiens presence in North and South America provides a considerably later date, around 14,000 BP. This time lag of an estimated 16,000 years remained an anthropological mystery for several decades until it was realized that Beringia was a habitable ecosystem during this period when glaciation blocked movement beyond Alaska. Faunal resources included bison, caribou, horses, lions, mammoths, musk-oxen, saga antelopes, and woolly rhinoceros, along with a variety of sea mammals (Brigham-Grette et al. 2004). For this entire period, all of Beringia except the southeast coast was free of glacial ice. It was rich in floral and faunal resources, with ocean shores the usual reliable source of food resources. The idea that Beringia had served as a habitable refuge for humans for an extended period was first suggested by Hulten (1937)), a botanist as well as geographer, who explored the region and published extensively on the rich flora of the region from the Yukon to Siberia, but his suggestion remained for decades little more than interesting speculation.

Most early discussions of human migration were speculative guesswork and remained so until hard scientific evidence emerged. The Eskimo-Aleut family of languages which ranges from Alaska across northern Canada is related to the easternmost 
branches of the Eurasiatic family (Ruhlen 1994, 169170) most notably Siberian-Yupik spoken by the Yupik people of the Chukotka Peninsula of northeast Russia, though linguistic similarities between North American and Asia languages provide soft evidence. The resemblances between northern Asian mythology and legends of Inuits, Eskimos, and First Nations tribes of Canada suggests continuities between Asia and North America that indicate what has been called a circumpolar culture, but these resemblances do not achieve the rigor of scientific evidence. Today, genetics has become the definitive arbiter.

At the inception of genetic studies, Torroni et al (1993) isolated four founding mtDNA haplogroups unique to archaic inhabitants of the Americas, identifying them as A, B, C, and D, which have become the first four letters of the phylogenetic alphabet. The theory of a "Beringian Standstill," put forward by Tamm et al (2007), based on Hulten's inventory of a supportive floral ecosystem, is also known as the Beringian Incubation Model, a term that captures what happened genetically. Over a period of approximately 16,000 years, four unique mutations were incubated through some 700 to 900 generations of Beringians. Eventually, A, B, C, and D were carried south as the four definitive mtDNA haplogroup markers of the founding population of the Americas.

\section{Peopling the Americas}

While Canada remained locked in glaciers, migration of archaic humans from Beringia was impossible: a 2000-mile trek of prehistoric Homo sapiens across glaciers rising hundreds of feet above the land without ready access to a food source was beyond possibility. Migration south had to await the waning of these glaciers. In the 1950s, glaciologists theorized that ice melt would have led to a separation of the eastern Laurentide glacier and the Cordilleran coastal glacier, resulting in a theoretical "ice-free corridor" along the eastern edge of the Rockies in the present Canadian province of Alberta. Leading into Montana, the corridor migration idea gained immediate popularity for several decades, partially because it led into the continental interior and thus suited the prevailing theory that the first Native American culture was the Clovis, named for a distinctive tool culture first unearthed deep in the American interior at Clovis, New Mexico.

The hold that the ice-free corridor maintained over the imagination is well illustrated in Dan Cushman's book The Great North Trail (1966). This is a great period piece written with a flair for telling detail that links up the Alaska-to-Montana route, "The Trail of All Ages," to numerous other northern trails-for instance the cattle trails - running north from Texas. His linking of various historical trails to the original migration route into the Americas reveals that he preferred a very broad and imaginative view of history; he could be considered an early big historian. This is particularly evident in his chapter, "The Trail of the Three-toed Horse," located at the center of the book, which explores the prehistory of the horse and in fact a variety of ancient megafauna. But his treatment of the Alaska-to-Montana route was too early for factually accurate information or a plausible account of archaic people's entry into North America.

Putting aside Cushman's "trail of all ages," his romanticized subtitle, through glaciated regions of Canada, this route was not available until some time after glacial melt set in around 16,000 BP; a navigable corridor would not have opened up until around 13,000 BP. While geologists have verified the possibility of this later ice-free corridor, its practicality was questioned by anthropologist Knut Fladmark (1979); any such corridor would run between 1,000-meterhigh ice cliffs. Thomas Canby (1979) suggested that it would be a "formidable place . . . an ice-walled valley of frigid winds, fierce snows, and clinging fogs." Brian Fagan $(1987,140)$ added that it was "at best, one of the most barren and impoverished landscapes that human beings could possibly exploit."

While Dan Cushman had imaginatively thought this route was possible, it was in fact bounded by hazardous ice cliffs, threatened by sudden ice falls, awash for centuries with freezing melt water, glacial lakes, and a constantly changing environment that would have 
delayed the development of a supportive ecosystem. A study of ancient DNA along the corridor route led by Eske Willerslev has worked out an evolutionary narrative of the corridor showing that a lack of floral resources, wood for fuel and tools, and game animals made the corridor "biologically unviable" before 12,600 BP (Wilken 2016). Additionally, no trace of human movement over the 1500 kilometer (1000 mile) route between Alaska and Montana has been discovered.

More than half a century ago, Wilson Duff' (1964, 7) hazarded a guess that "the Indian history of British Columbia . . . began at least a hundred centuries before the Province itself was born." His estimate has turned out to be a considerable underestimate. Critical of the ice-free corridor theory, Fladmark (1979) argued for a Pacific Coastal Route, which is now recognized as more probable for several reasons. The earliest effect of glacial melt was a drawback of the Cordilleran Glacier from the coast which exposed the beaches of southern Alaska and the continental margin of British Columbia. The establishment of a coastal floral ecosystem and faunal entry would follow within centuries, perhaps decades. According to Carol Mandryck et al (2001) "paleoecological data suggest that the coastal landscape was in part vegetated and probably able to support a terrestrial fauna, including humans." Lesnek at al (2018), have suggested a precise chronology: "Recent paleogenetic analyses suggest that the initial colonization from Beringia took place as early as 16 thousand years (ka) ago via a deglaciated corridor along the North Pacific coast. .. productive marine and terrestrial ecosystems were established almost immediately ... a an open and ecologically viable pathway through southeastern Alaska was available after 17,000 years ago."

While the ancient Pacific shoreline is now as much as 100 meters below present sea level, the exposed continental shelf extended far to the west of today's hazardous shoreline reefs and rocks. Early speculation that watercraft would be needed was imaginatively predicated on skirting the hazardous coast of cliffs, offshore rocks, and crashing surf of the continental margin all the way south to Oregon and Northern California, but this has been dismissed as probably beyond the construction skills of archaic Beringiansat least at this early date. The evidence suggests that a walkable coastal route was viable almost as soon as ice melt began, perhaps earlier. The outermost shore, often corresponding to the western margins of today's offshore islands - Prince Edward Island, Haida Gwaii, and Vancouver Island-were ice free and thus a suitable habitat for floral and faunal resources. Heaton (1996), for instance, has shown that Prince Edward Island on the southeast coast of Alaska was a refuge for the brown bear over a period of 40,000 years, an index of its suitability for a wide range of mammalian species, including human migrants.

One decisive piece of evidence is the presence of archaic Indians in a few sites in the Americas long before the ice free corridor was ecologically viable. An analysis of trace fossil coprolites from Paisley Caves led by Eske Willerslev (Gilbert 2008) indicates a human presence in Oregon by 14,000 BP, fourteen centuries before the ice free corridor could support human presence. Even more surprising is evidence from the Monte Verde site in Chile which shows that modern humans had reached it by $14,000 \mathrm{BP}$, a dating indicating an astonishingly rapid dispersal of early humans throughout the Americas. Additionally, it is almost impossible to imagine archaic humans traveling the interior for the whole length of the Americas so rapidly; too many habitable environments along the way would have waylaid dispersal. In contrast, littoral migration is likely to lead migrants forward. A mere ten miles per year - little more than a week of leisurely ambling - would have taken early migrants the length of the Americas in a single millennium.

\section{Trekking the Coast}

Keeping in mind the usual behavioral division between settlers and adventurers, we would expect a trail of relict settlements marking the passage south, left behind by adventurers who did not hesitate to 
move on. The later descendants of these settlers left a genetic trail that can be found in fossil remains. A surprising spectrum of evidence emerges from virtually every discovery. Excavations at $\mathrm{On}$ Your Knees Cave on Prince of Wales Island in southeastern Alaska have yielded a microblade and bifacial toolkit along with a 12,000+ BP skeleton remains - called "Shuka Kaa" ("Man Ahead of Us") by the Tlingit tribe of the region. A genetic marker (specifically mtDNA subhaplogroup D4h3) shows he is related to British Columbia tribes to the south - not only Tlingit, but also Haida, Nisga's, and Tsimshian, and in fact to Central and South American groups thousands of miles to the south, the Karitiana and Suruí, and the Ticuna of Brazil's Amazon (Kemp et al 2007; Bellwood 2013, 89). Here a single skeleton, combined with genetic collection along thousands of miles of coast, establish an ancient migration trail. This in fact is what we find all down the Pacific coast.

Farther south, the Haida Gwaii archipelago (formerly the Queen Charlotte Islands), located 45 to 60 kilometers (30 to 40 miles) off the mainland coast, was joined to it during the Glacial Maximum; today it is the stronghold of the Haida nation. Various caves$\mathrm{K} 1$, Gaadu Din 1 and 2 - have yielded stone tools from approximately 10,000 BP, evidence of Haida ancestors who are thought to have occupied Haida Gwaii since at least 13,000 BP with mitochondrial DNA and Y Chromosome evidence of descent from the ancient inhabitants of Beringia. Given the possible departure from Beringia as early as $16,000 \mathrm{BP}$, it is possible that additional evidence is awaiting discovery.

Access to seafood is a constant along the Pacific coast. Access to fresh water is equally reliable. Every few miles another stream pours off the coastal mountains, some still fed by glaciers, many more from Pacific moisture and rainfall as offshore winds rise over the coastal range. Numerous fiords provided access to both freshwater and salt water food. The present day Tsimshiam, Gitxsan, Haisla, and Wuikinuxv tribes of British Columbia occupy long-established inland riverine locations settled by coastal migrants.
In Washington State, the Makah, Quileute, Hoh, and Coastal Salish are permanent settlers where streams and rivers flow out of the rainforest of the Olympic Mountains. The attractiveness of inland riverine sites is evident with the Walapa tribe who settled inland along the Chehalis and Walapa Rivers. The Chinook tribe settled the mouth of the Columbia River and upriver more than 100 miles to Celilo Falls.

Careful consideration of the Pacific coast as the primary route for the peopling of the Americas lies in the inaccessibility of locations like Haida Gwaii and mainland fiords from any direction other than the north. The entire length and width of British Columbia is riddled with mountains from the coastal range east to the Rockies. These are geological young mountains - jagged and forbidding - assembled from collisions and subduction of the Pacific plate during the complex assembly of western North America. Barely accessible today from the interior except by highways to Prince Rupert and Vancouver, the entire coast was isolated from migrations from the interior, certainly from migratory groups, if any, that might have traveled all the way to Montana before exiting the Ice Free Corridor. The three groups that dominate Vancouver Island, the largest island off the west coast of the Americas, have genetic connections with coastal populations to the north and south; interior genetic markers are derivative. Rich in floral, faunal, and marine resources with warm offshore currents, Vancouver Island is home to three groups, all of which have become well known. The Kwakiutl gained prominence from the novel by Margaret Craven, I Heard the Owl Call My Name (1967), which made the New York Times Bestseller List once it was picked up by an American publisher. The Nuu Chah Nulth are known from the adventures of John R. Jewett (17831821) who survived a 28-month captivity with this group and wrote a memoir of great anthropological interest-Narrative of the Suffering of John R. Jewett (1815). The Coastal Salish occupied coastal regions from Vancouver Island with a prominent presence in the American Northwest. Habitation locations from 
southeast Alaska to Washington State are most clearly understood as relict sites marking the trail of Beringian migrations southward along the coast.

Recently Duncan McLaren et al (2018) discovered 29 archaic human footprints of various sizes on the shore of Calvert Island, British Columbia, dating to 13,000 BP. On Santa Rosa Island, twenty miles off the coast of Santa Barbara, some twenty sites of human occupation have been identified, dating between 12,000 and 11,000 BP. Evidence includes tool-making sites, stone points, and substantial middens of abalone shells (Rick et al. 2013). Genetic and archeological evidence have coalesced to establish the Western Coast Route as the primary migration route into the Americas.

As suggested earlier, successful reconstruction of early migration routes is possible because of constants in human behavior. Some migrants are prepared to settle in a new location if environmental conditions of climate, food, and water are favorable. It is possible that this describes the majority, and most likely elder members of migrating groups. Stability and regional reliability of food resources may encourage expansion up and down the coast and perhaps inland along a waterway where harvesting of riverine resources adds to their diet. The result may be an expansive relict community. Centuries or millennia later, these relict communities preserve genetic markers, making such communities milestones along the original migration route. Meanwhile, adventurers and explorers become restless, choose independence, and move on. Predictably, these will be younger members of the group. They carry the genetic markers of their forebears, but in time new markers emerge that extend the overall direction of migration.

Among the migrants along the primary coastal route into the Americas one would expect more settlers than adventurers and thus a considerable density of settlement population, and, in fact, this

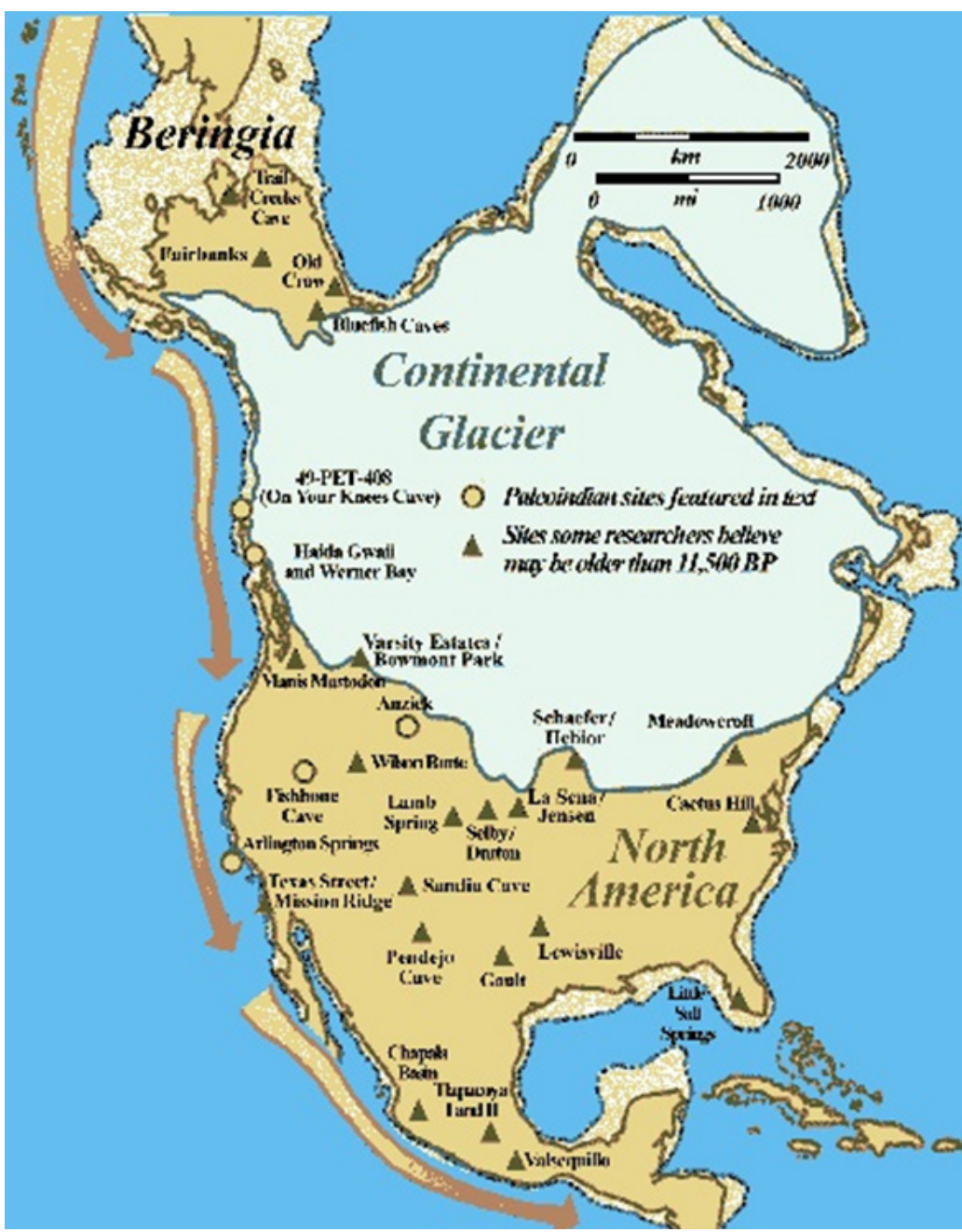

Figure 7. The West Coast Route into the Americas has emerged as the most viable way past glaciers during the last Ice Age when shorelines were seaward of present locations. Paleoindian sites on the coast and in the interior indicate rapid dispersal across the continent. Note that the ice-free corridor, once illustrated on virtually every migration map, has here been eclipsed by definitive evidence for the coastal route. Image source: www.TranspacificProject.com

is the case. Coastal First Nations tribes of British Columbia and Native American tribes of Washington and Oregon number more than fifty; another fifty occupied California with subgroups adding another forty. Numerous dispersal routes into the interior were available: the Fraser River of British Columbia, the Skagit and Columbia Rivers of Washington, the Umpqua and Rogue Rivers of Oregon, the Klamath 
and Salinas Rivers of California, and the Colorado River from Mexico. While all presented congenial sites for settlement, those who followed these inland routes were in the minority. Even today, the west coast of both Canada and the United States have the greatest density of indigenous population, with one-third of Native Americans living in California. This reflects their west-coastal entrance into the Americas as surely as the arrival of Europeans on the Atlantic coast is reflected in their greater density along the east coast.

\section{The Central and South American Coastal Route}

The huge land masses of North and South America have led to Mexico and particularly Central America regarded primarily as a land bridge, particularly where it narrows to 50 kilometers ( 30 miles) at the Isthmus of Panama. Certainly, an inventory of prehistoric sites in South America indicates that numerous groups trekked through and well beyond Central America. Though most evidence of coastal settlement may await discovery - or may remain far below today's higher sea level - Central America offered congenial inland environments for settlements that eventually developed into advanced civilizations supported by water-managed cultivation of maize, beans, squash, tomatoes, chilies, and amaranth. The Toltecs developed agriculture enhanced with dams and water channels along Gulf Coast river valleys. The later Aztecs, who gained control from the Gulf of Mexico to the Pacific, developed agriculture using a chinampas system of raised growing beds and water channels. The Mayans developed a similar raised-bed agriculture along with terrace farming in the Yucatan Peninsula. Toltec civilization was based on centuries, perhaps millennia, of in situ settlement such that they developed an advanced sculpture tradition; both the Aztecs and the Mayans constructed monumental civilizations of quarried stone with considerable social complexity and associated political organization reminiscent of Old World cultures of the Nile, Tigris-Euphrates, and Indus River Valleys.

While these Central American civilizations developed on an agricultural foundation, many early migrants moved beyond to the southern continent. In a survey of the late Pleistocene in South America, Tom Dillehay (1999, Fig. 1) mapped 41 sites, more than 20 of them west of the Andes along the Pacific coastal route from Columbia to Patagonia.

Coastal Peru may eventually yield evidence of archaic migrant passage and settlement, though scores of well-developed sites in the Peruvian Andes testify to congenial climate and supportive resources that resulted in stable settlements lasting centuries or millennia. On the coast of Ecuador, a cluster of sites has revealed reliance on marine food resources, including tidal zone and estuary mangrove waters. Some 32 archaic sites have been identified on the Santa Elena Peninsula, known collectively as the Las Vegas site. Site 80, 3 kilometers (2 miles) from the coast, is characterized by a 4,000-year-old midden, the lowest level of which has been carbon dated to 10,400 BP (Stothert 1988). However, nearby beachside camps and shell middens indicate shortterm or occasional occupation and reliance on faunal and floral foods, but also marine resources, inventoried as 25 varieties of fish, 1 crustacean, and 15 mollusks. Stothert $(2011,373)$ estimates the occupants of Las Vegas site 90 relied on marine and estuary resources for half their food. The species consumed were almost all shallow water species, suggesting almost daily fishing while wading rather than reliance on any kind of water craft. The dominance of mangrove clam shells $(57-80 \%)$ may indicate the convenience of harvesting nearby mangrove waters. Lacking evidence otherwise, shallow water harvesting likely characterized marine harvesting throughout the entire coastal migration out of Africa. Long occupation provides evidence that applies to every relict coastal settlement: marine resource reliability accounts for the primacy of beachcombing and coastal settlement that characterized prehistoric life.

In 1975, anthropologist Tom Dillehay discovered an open-air site in Chile on a river tributary at Monte Verde, 58 kilometers (38 miles) from the Pacific coast. The importance for the chronology of migration in the New World and the wealth of artifacts recovered at this 
site have been discussed in detail (Fagan 1987, 174175; Dillehay 1999, 2000; Bellwood 2013). Preserved by a peat-filled bog, the site yielded bones, charcoal, pieces of hide clothing, remains of posts from a dozen huts, and a piece of meat from which DNA could be extracted. The site, dated to $14,800 \mathrm{BP}$ appears to have been occupied by a typical foraging group of around 30 individuals with evidence of a mixed floral, faunal,

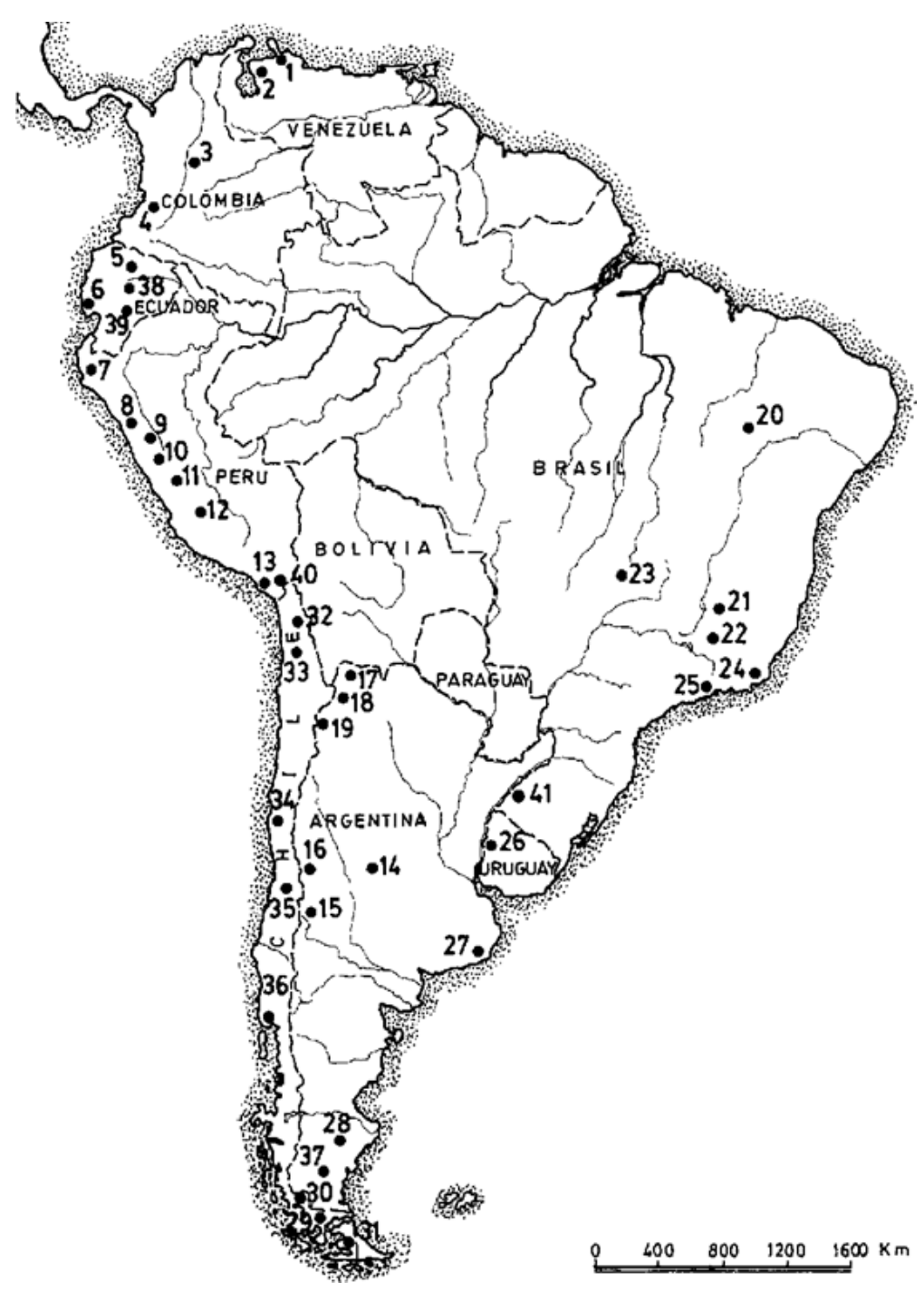

Figure 8. A proliferation of late Pleistocene sites west of the Andes marks the primary coastal migration route. The following sites are referred to in the text: 6. Las Vegas; 30. Mylodon Cave, Cueva del Medio; 36. Monte Verde. Map source: Dillehay 1999. and marine diet. As noted earlier, the dating of Monte Verde, which predates a viable ice-free corridor through Canada by many centuries, provides primary confirmation of a coastal rather than inland migration, though the early arrival at Monte Verde provides an astonishing scenario of 10,000 miles of rapid peopling of South America. In this connection, Peter Bellwood $(2013,91)$ suggests that a migrant population could have "made its way down the long western edge of the Americas in just two short millennia between 16,000 and 14,000 years ago. . . . A few hundred pioneers doubling their population every 50 or 100 years or so would have had little difficulty in traversing such a distance very quickly, and keeping contact with other groups left behind." Monte Verde is in fact the oldest confirmed site in the Americas. A relative lack of stone tools indicates that this group did not rely on hunting but were primarily foragers, depending on floral gathering and harvesting of marine resourcesundoubtedly a legacy of millennia of trekking ocean coasts.

The final leg of this human odyssey occurred when humans reached Patagonia, the southern extremity of South America. The Milodon Cave ("Cueva del Milodon"), now a National Monument, is named for remnants of the prehistoric Milodon that went extinct in excess of 10,000 BP. Fire-fractured stone and lithic tools have been recovered from the cave along with human remnants. Off the west coast route but located on the Pinturas River of Argentina, the Cave of the Hands ("Cueva de Las Manos") shows evidence of occupation as early as 13,000 BP. Its art work from which it takes its name features numerous stenciled hands, carbon dated from the bone-made pipes used to spray paint at 9300 BP. Similar images of hands, nearly always the left hand, are well known from Neolithic cave art in France.

The 2500-mile coast of Chile, which includes Patagonia, and the Tiera de Fuego archipelago, 


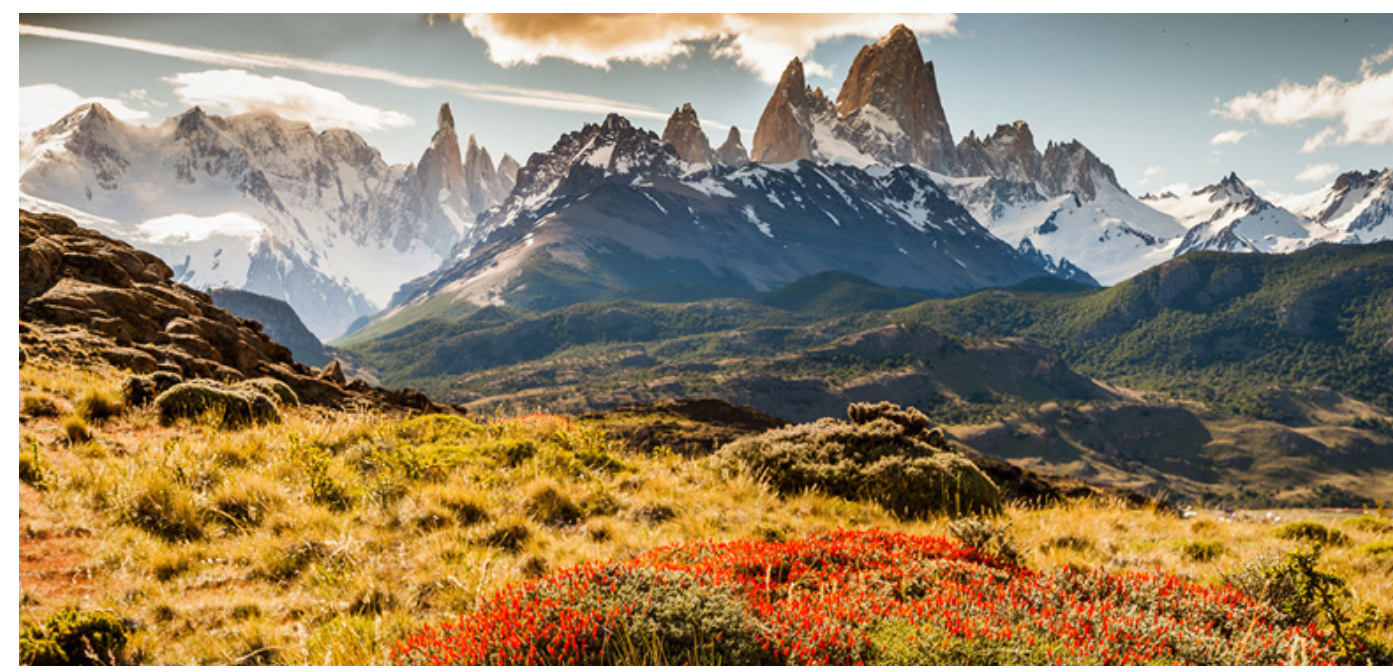

Figure 9. Patagonia, the final stop on the great migration, is a hostile environment of numerous islands, ragged mountains, inland waterways, and rich marine resources that have served Homo sapiens migrants for thousands of years.

Image source: www.patagonia.com. "constantly changing lifestyle of Homo sapiens resulting from having traversed the entire span of the Western Hemisphere." His focus on the coastal environment might well apply to the entire oceanmargin migration with its constantly reliable marine resources that led humans from South Africa to Patagonia, a trek that unfolded over more than 60,000 years. National Geographic (March 2006) called it "the greatest journey ever told." is one of the most hostile coasts of the world. Islands number 4,872 with few inhabited and most inhospitable.

The region is rich in seafood along hundreds of miles of inland waterways. Spa Piana and Orquera (2009) have pointed out that the settlers of Patagonia and Tierra del Fuego "became intensely dependent on the littoral and marine resources and designed special technological means for their procurement and processing, including navigation." Given the extent of islands and waterways at the extremity of South America and the near-freezing temperatures of ocean waters, it is likely that migrants to Patagonia were impelled to developed watercraft at an early date, perhaps within a century or two following their arrival.

In assessing the early settlement of South America, Tom Dillehay (1999, 206-207) writes, "Being the last continent occupied by humans but one of the earliest where domestication occurred, South America offers an important study of rapid cultural change and regional adaptation." Among a number or richly suggestive "triggering mechanisms," Dillehay points to the coastal environment, particularly the

\section{Interior Riverine Migration}

Bringing together diverse discoveries and focused excavations from around the world allows us to construct a primary route for the peopling of the world. Organized chronologically into a continuous narrative, secondary migrations come into focus. In addition to a constant, reliable food source provided by marine resources, humans need daily access to fresh water. This makes streams and river mouths along ocean coasts the necessary stopping points for coastal migrants. Between South Africa and Patagonia these number in the hundreds. Offering freshwater riverine resources, most streams flowing from interior uplands would invite upstream migration. In some cases, such riverine migrations would open up congenial environments away from ocean storms and winds.

With this in mind, we can point to inland riverine settlement from which we can infer prehistoric foraging migration. The Tigris-Euphrates valley, as noted earlier, provides the first route of dispersal separation from the primary coastal route. Mesopotamia and the surrounding hills are the most excavated in the world; traces of prehistoric settlements and worksites in the 
surrounding Zagros Mountains number in the hundreds, suggesting long occupation and population growth. Charles Keith Maisels $(1990,124)$ estimates that the region eventually harbored 2000 to 4000 foraging groups of 50 to 100 members. Later Mesopotamian cities - Ur, Eridu, Nippur, Kish, Babylon, and Marimay well have occupied early settlement sites no longer accessible. In addition, the Tigris-Euphrates route north provided a migration corridor which, with minor directional changes, points northwest toward Anatolia (Turkey), the doorstep of Europe, and directly north toward the interior of Asia. Somewhere just east of the Horn of Africa, haplogroups N (mtDNA) and R (Y DNA) evolved from the M haplogroup, probably as early as 80,000 BP. Torroni et al (2006) argue that M, N, and R occurred between East Africa and the Persian Gulf; the presence of $\mathrm{N}$ and $\mathrm{R}$ across the entire Eurasian region to the north suggests that riverine routes north on the Tigris and Euphrates may well be a secondary route of great importance in populating the north.

Farther east on the South Asian coastal route, the Indus River invited migrants to the uplands of Pakistan where, much later, dozens of congenial riverine sites were established that eventually evolved into an immense civilization. The sites of the now ruined cities of Harappa and Mohenjo Daro were probably occupied by some of the earliest riverine migrants away from ocean shores. On the west coast of India the Narmada and Tapi Rivers provided routes to the central interior of India, but the majority of peninsular India rivers arose in the west and flowed east to the Bay of Bengal-among them the Krishna and Godivari with their numerous tributaries, and the Brahmani and Mahanadi Rivers. The grandfather of all inland riverine routes followed the Ganges and its numerous tributaries, which form a vast fertile watershed fed by Himalayan glaciers. It is the second largest watershed on the planet, draining $1,086,000 \mathrm{~km}^{2}$, including parts ofBangladesh, Nepal, and Pakistan. The environmental richness of the Indian subcontinent, including riverine food resources, undoubtedly attracted numerous inland settlements in prehistoric times, and eventually one of the richest cultures on the planet; here, both Hinduism and Buddhism were born.

Farther east, the Irawaddy River of Myanmar provided a similar route into the Himalayan foothills with long-occupied locations evolving into the later sites of Yangon (Rangoon), Paya (Prome), Bagan, and Mandalay. The rich environment and monumental structures of Angkor covering 400 square kilometers on a tributary of the Mekong River suggests it may have developed on archaic sites of riverine migrants in Kambodja (Cambodia) millennia earlier. In China, the Huang Ho (Yellow River) stretching 5464 kilometers (3395 miles) deep into the continent was the site of prehistoric settlement where Chinese civilization first emerged. Heavily populated and ravaged by numerous flood events, it is likely that most archaic sites have been washed away, though any of ten major cities on the Huang Ho may be located where precivilized Homo sapiens first settled. To the south, the multi-tributary Yangtse River, the longest river in Asia, flows 6380 kilometers (3964 miles), past dozens of riverine sites, including Nanying and Shanghai, before emptying into the Pacific. While some migrants reached China from the western interior, these East Asian Rivers provided the most accessible, reliable, and probably the earliest routes into the interior from the primary coastal route.

In North America, the Fraser River, stretching 1375 kilometers (854 miles) provided a route into the interior valleys of British Columbia. Following the border of Washington State and Oregon, the Columbia River, with Okanagan, Bitterroot, and Snake River tributaries, provided a 2000 kilometer (1200 mile) riverine route to the Rockies of Canada and the United States. First Nations and Native America sites of the Pacific Northwest interior reflect inland riverine migrations of archaic migrants. Emptying into San Francisco Bay, the Sacramento and San Joachin Rivers, with dozens of tributaries flowing out of the Sierra Mountains, provided riverine migration routes into most of the California interior. The Colorado River 
and its Green River tributary provided similar access into Arizona and Utah, regions east into New Mexico and Colorado, and north to Wyoming. The efficacy of this route is clear, for instance, in the discovery of the Native American Palisades kiva by the Colorado River in the depths of the Grand Canyon (Harvey 2008) - a structure familiar from the elaborate ruins of the Anasazi in Chaco Canyon.

From the primary coastal route, riverine routes provided access to most of South Asia, East Asia, and North and South America. The geographical configuration of Europe, however, provided a different scenario. With the exception of rivers flowing into the Black Sea - the Dneiper and Danube - that could lead migrants into the European hinterlands, riverine migration along waterways flowing westward into the Atlantic Ocean - the Loire, Seine, Rhine. Elbe, and Vistula-led migrants downstream from sources deep in the interior.

\section{The Greatest Adventure}

By the time coastal migrants left Africa, they had accumulated as much as 100,000 years of expertise gathering, hunting, and surviving on marine resources on the south and eastern margins of the continent. The rapid dispersal across South Asia to East Asia added collective experience with a variety of riverine and lacustrine environments over perhaps another 50,000 years. In the coastal archipelagos of Southeast and East Asia, Homo sapiens were motivated to develop durable watercraft, a trial-and-error process that may have occurred over millennia with exploration confined to island waterways. Whether powered by sail or oar remains a matter of speculation, though the use of both by Phoenicians, Greeks and Romans during approximately the same era suggests similar navigation methods along Asian coasts. Undoubtedly, ways of collecting rainwater combined with wellhoned skills of harvesting marine resources allowed for lengthy adventuring along coasts and among hundreds of islands. At some point, such adventuring expanded into Pacific Ocean exploration.
Seventy years ago, Thor Heyerdahl popularized the idea of oceanic drifting with prevailing winds and ocean currents in his Kon-Tiki expedition, but his premise of Pacific island populating from South America has not stood up to genetic analysis of the islanders. Nevertheless, drifting with currents and winds undoubtedly played a part in ocean exploration from Southeast and East Asia. K. R. Howe (2003) has made a case for the earliest explorers rowing or powering into the wind with some confidence that they could reliably backtrack by simply drifting or sailing with the wind. By analogy with the perceptual skills of primitive contemporaries today, we can assume navigation by the Sun, Moon, and stars as a virtual certainty. Familiarity with the seasonal changes in constellation movement along with prevailing sea currents eventually led to confidence, laced with daring and unimaginable bravery, on the open sea.

Sometime around $3500 \mathrm{BCE}$, adventurers set off on sea voyages that eventually led to the settlement of the Bismarck and Solomon Islands east of New Guinea; then, over the next 4,000 years, Melanesia, Micronesia, and Polynesia. Other scenarios have them departing from the Philippines. Undoubtedly, adventuring beyond the sight of land had occurred with regularity before the greatest exploration adventures began. Nevertheless, the enormous distances between the mainland and Pacific Islands defines this adventure as an act of supreme risk, especially considering the size of this largest ocean on Earth. The odds against making landfall meant that some adventurers, perhaps many, must have been lost; on the other hand, survival skills were well advanced: survival on the ocean over several weeks was possible, thus increasing the odds of reaching landfall. Expedition numbers are impossible to know; there may have been dozens of departures generations apart. Returns may have been few; losses are guesswork. What we do know is that within 3,000 years an extensive array of Pacific Islands was well populated, all the way to Easter Island thousands of miles away from the Asian mainland. 
Genetic analysis has made it possible to trace these Pacific island migrations. Linguistic similarities provide expected verification. Cultural continuities illustrate the migration sequences of island hopping and settlement. Similar ritual patterns provide a narrative thread. Island living presented problems never encountered on the mainland where population increase or soil depletion could be ameliorated by simply moving on. Such problems within the confined boundaries of islands forced adaptation that was not always successful; the apparent collapse of living conditions on Easter Island and its diminished population provides the most dramatic example, possibly illustrating environmental or social breakdown, or both. But sometime between 1200 and $900 \mathrm{CE}$ adventurous seafarers sailing north from French Polynesia spotted islands on the horizon and perhaps the rising smoke of eruption from the Kilauea volcano on the Big Island of the Hawaiian archipelago. They pressed on, carrying along their powerful deities led by the goddess Pele, who adopted the Hawaiian volcanos as her own as these migrants adopted these islands as their own. As they pulled their outriggers ashore, they brought to completion a 100,000 year epic of the peopling of the Earth. The greatest journey ever made came to an end on the beaches of the most isolated islands on the planet.

\section{Acknowledgments:}

Copyright holders have been informed of images, maps, and photographs here included for education and scholarship purposes conforming to "fair use" under U.S copyright law. I would like to thank the anonymous reviewers who undertook close readings of the draft, provided helpful editing suggestions, and pointed out additional sources relevant to the paper.

\section{References}

Ardrey, Robert. 1963. African Genesis: A Personal Investigation into the Animal Origins and Nature of Man. London: Harper Collins.

Armitage, S. J. et al. 2011. "The Southern Route 'Out of Africa'Evidence for an Early Expansion of Modern Humans in Arabia." Science 331: 453-456.

Atkinson, Q.D. 2008. "mtDNA Variation Predicts Population Size in Humans and Reveals a Major Southern Asian Chapter in Human Prehistory." Molecular Biological Evolution 25, 466-474. Doi.10.1093/molbev/msm277

Atkinson, Q.D., R.D. Gray, A.J. Drummond. 2009. "Bayesiasn Coalescent Inference of Major Human Mitochondrial DNA Haplogroup Expansions in Africa." Proceedings Royal Society B 276, 367-373. Doi:10.1098/rspb.2008.0785

Behar, D.M. et al. 2008. "The Dawn of Human Matrilineal Diversity." The American Journal of Human Genetics 82" 1130-1140.

Bellwood, Peter. 2013. First Migrants: Ancient Migration in Global Perspective. Oxford: John Wiley \& Sons.

Bellwood, Peter. 2017. First Islanders: Prehistory and Human Migration in Island Southeast Asia. Oxford: John Wiley \& Sons.

Berger, Lee R. et al. 2003. "Preliminary Results of Excavations at the Newly Investigated Coopers D Deposit, Gauteng, South Africa : Preliminary Research Reports : Human Origins Research in South Africa." South African Journal of Science. 99 (5-6): 276-278.

Bicho, Nuna F. et al. 2011. Trekking the Shore: Changing Coastlines and the Antiquity of Coastal Settlement. New York: Springer.

Brigham-Grette, J. et al 2004. "Paleoenvironmental Conditions in Western Beringia Before and During the Last Glacial Maximum.” In D. B. Maden, ed. Entering America, 29-32. Salt Lake City: University of Utah Press.

Broadhurst, C. L. et al. 1998. "Rift Valley Lake fish and Shellfish Provided Brain-specific Nutrition for Early Homo." British Journal of Nutrition, Vol. 79: 3-21.

Broadhurst, C. L. et al. 2002. "Brain-specific Lipids from Marine, Lacustrine or Terrestrial Resources: Potential Impact on Early African Homo sapiens." Comparative Biochemistry and Physiology Part B 131: 653-673. 
Brown, Kyle S. et al. 2009. "Fire as an Engineering Tool of Early Modern Humans." Science Vol. 325: 859-862.

Canby, Thomas. 1979. "The Search for the First Americans." National Geographic, Vol. 156, No. 3 (September): 330-363.

Cann, Rebecca L. et al. 1987. "Mitochondrial DNA and human evolution." Nature 325: 31-36.

Capelli, Cristian et al. 2001. "A Predominantly Indigenous Paternal Heritage for the Austronesian-Speaking Peoples of Insular Southeast Asia and Oceania." American Journal of Human Genetics 68 (2): 432-443,

Chang JG, et al. 2002. "Molecular Analysis of Mutations and Polymorphisms of the Lewis Secretor Type Alpha $(1,2)$--fucosyltransferase Gene Reveals that Taiwanese Aborigines are of Austronesian Derivation." Journal of Human Genetics 47 (2): 60-65.

Clarkson, Chris. 3017. "Human Occupation of Northern Australia by 65,000 Years Ago." Nature Vol. 547: 306-310.

Crawford, M. A. et al. 1999. "Evidence for the Unique Function of Docosahexaenoic Acid during the Evolution of the Modern Hominid Brain.” Lipids, 34, Supplement. 539-547.

Craven, Margaret. 1967. I Heard the Owl Call My Name. Toronto: Clark-Irwin.

Cunnane, S. C. et al. 1993. "The Importance of Energy and Nutrient Supply in Human Brain Evolution." Nutrition and Health, 9 219-235.

Cushman, Dan. 1966. The Great North Trail: America's Route of the Ages. New York: McGraw Hill.

Cyran, K. A. et al. 2010. "Alternatives to the Wright-Fisher Model: The Robustness of Mitochondrial Eve Dating." Theoretical Population Biology, 78.3: 165-172.

Dart, Raymond A. 1925. "Australopithecus africanus: The ManApe of South Africa." Nature Vol. 115, No. 2884: 195-199.

Dillehay, Tom D. 1999. "The Late Pleistocene Cultures of South America." Evolutionary Anthropology. 7 (6): (11 May) 206216. doi:10.1002/(SICI) 1520-6505(1999)7:6<206::AIDEVAN5>3.0.CO;2-G.

Dillehay, Tom D. 2000. The Settlement of the Americas: A New Prehistory. New York: Basic Books.

Dixon, E. J., 1997 Late Quaternary Regional Geoarchaeology of Southeast Alaska Karst: A Progress Report. Geoarchaeology 12 (6): 689-712.
Duff, Wilson. 1964. The Indian History of British Columbia: Volume 1 The Impact of the White Man. Anthropology in British Columbia Memoir No. 5. Victoria: Province of British Columbia Department of Recreation and Conservation. p. 7.

Fagan, Brian. 1987. The Great Journey: The Peopling of Ancient America. London: Thames \& Hudson.

Fagundes, N.J.R. et al. 2007. "Statistical Evaluation of Alternative Models of Human Evolution." Proceedings of the National Academy of Sciences 104, 17614.

Faure Hugues, et al. 2002. "The Coastal Oasis: Ice Age Springs on Emerged Continental Shelves." Global Planetary Change $33,47-56$.

Fladmark, Knut. (1979), Alternate Migration Corridors for Early Man in North America." American Antiquity, Vol. 44, No. 1. 55-69.

Fu, Q. et al. (2013). "A Revised Timetable for Human Evolution Based on Ancient Mitochondrial Genomes." Current Biology, Vol. 23: 553-559.

Gilbert, M. T. P. (2008). "DNA from Pre-Clovis Human Coprolites in Oregon, North America". Science, 320, No. 5877): 786-789.

Goebel, T. 2002. "The 'Microblade Adaptation' and recolonization of Siberia during the Late Upper Pleistocene." Archaeological Papers of the American Anthropological Association, Vol. 12: 117-131.

Goebel, T. et al. 2010. "New Dates from Ushki-1, Kamchatka." Journal of Archaeological Science, Vol. 37: 2640-2649.

Gonder, M.K. et al. 2007. "Whole-mtDNA Genome Sequence Analysis of Ancient African Lineages." Molecular Biology and Evolution 24: 757-768.

Groucutt, Huw W. et al. 2018. "Homo sapiens in Arabia 85,000 Years Ago.” Nature Ecology Evolution 2.5: 800-809.

Harvey, Gareth, Producer. 2008. Grand Canyon: America's Wild Spaces. National Geographic.

Heaton, T. H. 1996. "An Ice Age Refugium for Large Mammals in the Alexander Archipelago, Southeast Alaska." Quaternary Research 46:186 - 192.

Henderson, 2010. "Archaeologists Unearth 67,000-year-old Human Bone in Philippines". The Daily Telegraph.

Heyerdahl, Thor. 1949. Kon-Tiki. London: George Allen and Unwin. 
Howe, K. R. 2003. The Quest for Origins: Who First Discovered and Settled the Pacific Islands? Honolulu: University of Hawaii Press.

Hublin, Jean-Jaques. et al. 2017. "New fossils from Jebel Irhoud, Morocco and the pan-African Origin of Homo sapiens." Nature 546, 289-292.

Hultén Eric. 1937. Outline of the History of Arctic and Boreal Biota during the Quaternary Period. New York: Lehre J. Cramer.

Iakovleva L, and Djindjian F. 2005. "New data on Mammoth bone settlements of Eastern Europe in the light of the new excavations of the Gontsy site (Ukraine)." Quaternary International 126-128:195-207.

Jefferson, Thomas. 1954. Notes on the State of Virginia. Chapel Hill, NC: University of North Carolina Press.

Jewett, John R. 1815. The Adventures of John Jewitt : Only Survivor of the Crew of the Ship Boston during a Captivity of Nearly Three Years Among the Indians of Nootka Sound in Vancouver Island.

Kemp, B. et al. 2007. "Genetic Analysis of Early Holocene Skeletal Remains from Alaska and Its Implications for the Settlement of the Americas." American Journal of Physical Anthropology 132: 605-621.

Kuzmin, Y. et al. 2007. "Introduction: Microblades and Beyond," In Kuzmin, Y. et al. eds. Origin and Spread of Microblade Technology in Northern Asia and North America, 1-6. Burnaby, British Columbia: Archaeology Press.

Leakey M, Hay R. 1979. "Pliocene footprints in the Laetoli Beds at Laetoli, Northern Tanzania.” Nature. Vol. 278: 317-323.

Lee, R. B. and I. DeVore, eds. 1968. Man the Hunter. Chicago: Aldine.

Lewin, Roger. 1987a. “Cradle of Modern Humans.” Science, Vol. 237, 1292-1295.

Lewin, Roger. 1987b. "The Unmasking of Mitochondrial Eve." Science, Vol. 238, No. 4823: 24-26.

Lesnek, Alia J. et al. 2018. "Deglaciation of the Pacific Coastal Corridor Directly Preceded the Human Colonization of the Americas." Science Advances Vol. 4, no. 5 (30 May). DOI: 10.1126/sciadv.aar5040.

Liu, Yichang. 2009. "Zuozhen Man.” Encyclopedia of Taiwan. Archived from the original on 2012-07-15.
Macaulay, Vincent et al. 2005. "Single, Rapid Coastal Settlement of Asia Revealed by Analysis of Complete Mitochondrial Genomes," Science, Vol. 308: 1034-1036.

Maisels, Charles Keith. 1990. The Emergence of Civilization: From Hunting and Gathering to Agriculture, Cities, and the State in the Near East. London: Routledge.

Malyarchuk, Boris. 2011). “Ancient Links between Siberians and Native Americans Revealed by Subtyping the Y Chromosome Haplogroup Q1a." Journal of Human Genetics. 56: 583-588.

Mandryck, Carole A. S. et al. 2001. "Late Quaternary paleoenvironments of Northwestern North America: implications for inland versus coastal migration routes." Quaternary Science Reviews Vol. 20, Issues 1-3, (January), 301-314.

Marean, Curtis. 2007. "Early Human Resources of Marine Resources and Pigment in South Africa during the Middle Pleistocene." Nature, Vol. 449: 905-908.

Marean, Curtis. 2011. "Coastal South Africa and the Coevolution of the Modern Human Lineage and the Coastal Adaptation." In Bicho, et al. 421-440.

Marean, Curtis. 2012. "When the Sea Saved Humanity." Scientific American: Special Editions 22 (December), 52-59.

Marshack, Alexander. 1972. The Roots of Civilization: The Cognitive Beginnings of Man's First Art, Symbolism and Notation. London: Moyer Bell, Ltd.

Matsu'ura, Shuji. 1999). "A Chronological Review of Pleistocene Human Remains from the Japanese Archipelago." Interdisciplinary Perspectives on the Origins of the Japanese: 181-197.

McLaren, Duncan et al. 2018. "Terminal Pleistocene Epoch Human Footprints from the Pacific Coast of Canada." PLoS ONE, Vol. 13, No. 3. Open access.

Nakagawa, Ryohei. 2010. "Pleistocene Human Remains from Shiraho-Saonetabaru Cave on Ishigaki Island, Okinawa, Japan, and their Radiocarbon Dating." Anthropological Science. The Anthropological Society of Nippon. 118 (3).

Olsen, John W. et al. 1992. "The Palaeolithic in Southern China." Asian Perspectives 31 (2): 129-160.

Olson, Steve. 2002. Mapping Human History: Discovering the Past Through Our Genes. Boston: Houghton Mifflin. 
Oppenheimer, Stephen. 2003. The Real Eve: Modern Man's Journey Out of Africa. New York: New York: Basic Books.

Oppenheimer, Stephen. 2012. "Out-of-Africa, The Peopling of Continents and Islands: Tracing Uniparental Gene Trees Across the Map." Philosophical Transactions of the Royal Society B.

Petit, J. R. et al. 1999. "Climate and Atmospheric History of the Past 420,000 Years from the Vostok Ice Core, Antarctica. Nature, Vol 399: 429-436.

Piana, Ernesto L. et al. 2009. "The Southern Top of the World: The First Peopling of Patagonia and Tierra del Fuego and the Cultural Endurance of the Fuegian Sea-Nomads." Arctic Anthropology Vol. 46, No. 1/2, 103-117.

Quintana-Mirci, Lluis O. et al.1999. "Genetic Evidence of an Early Exit of Homo sapiens from Africa through Eastern Africa." Nature Genetics 23, 437-441.

Raichlen D, Gordon A, Harcourt-Smith W, Foster A, Haas W. Laetoli Footprints Preserve Earliest Direct Evidence of Human-Like Bipedal Biomechanics. PLOS ONE. 2010;5:e9769. pmid:20339543.

Reich, David. 2018. Who We Are and How We Got Here: Ancient DNA and the New Science of the Human Past. New York: Pantheon Books.

Richter, D. et al. 2017. "The age of the hominin fossils from Jebel Irhoud, Morocco, and the origins of the Middle Stone Age." Nature, Vol. 546, 293-296.

Rick, Torben C. et al. 2013. "Archaeological Survey, Paleogeography, and the Search for Late Pleistocene Paleocoastal Peoples of Santa Rosa Island, California." Journal of Field Archaeology, Vol. 38, No. 4: 324-331.

Rose, Jeffry I. et al. 2011. "The Nubian Complex of Dhofar, Oman: An African Middle Stone Age Industry in Southern Arabia." PLOS ONE, 6. Open access.

Ruhlen, Merritt. 1994. The Origin of Language: Tracing the Origin of the Mother Tongue. New York: John Wiley \& Sons.

Sauer, Carl O. 1962. "Seashore-Primitive Home of Man?" Proceedings of the American Philosophical Society Vol. 106, No. 1 (Feb. 15, 1962), pp. 41-47.

Schlebusch, C. M. et al. 2017. "Southern Africa Ancient Genomes Estimate Modern Human Divergence to 350,000 to 260,000 Years Ago." Science, 358, No. 6363: 652-655.

Shinoda, Ken-ichi, and Noboru Adachi. 2017. "Ancient DNA
Analysis of Palaeolithic Ryukyu Islanders." Terra Australis. Canberra, Australia: ANU Press. 45: 51-59.

Shurr, T. G.; S. T. Sherry. 17 June 2004. "Mitochondrial DNA and Y chromosome diversity and the peopling of the Americas: Evolutionary and demographic evidence." American Journal of Human Biology 16: 420-439.

Shurr, T. G. 2015. "Tracing Human Movements from Siberia to the Americas: New Insights from Genetic Studies.” In M. B. Franchetti et al. Editors. Mobility and Ancient Society in Asia and the Americas. Basel: Springer. 23-47.

Skoglund, Pontus, et al (2017). "Reconstructing Prehistoric African Population Structure.” Cell, Vol. 171, Issue 1, 59-71.

Stothert, Karen E. 2011. "Coastal Resources and the Early Holocene Las Vagas Adaptation of Ecuador.'In Nuno F. Bicho, ed. Trekking the Coast. 355-382.

Tamm, Erika, et al. 2007.. "Beringian Standstill and Spread of Native American Founders." PLOS ONE. 2 (9): e829.

Takashi, Tsutsumi. 2012. "MIS3 Edge-ground Axes and the Arrival of the first Homo sapiens in the Japanese Archipelago." Quaternary International Vol. 248, 70-78. 248: 70-78.

Thackeray, J. F. 1988. "Molluscan Fauna from Klasies Cave, South Africa." The South African Archeological Bulletin, 43: 27-32.

Thangaraj, Kumarawamy et al. 2003. "Genetic Affinities of the Andaman Islanders, a Vanishing Human Population." Current Biology Volume 13, Issue 2, 86-93.

Thangaraj, Kumarasamy, et al. 2005. "Reconstructing the Origin of Andaman Islanders." Science Vol. 308, Issue 5724, pp. 996. DOI: 10.1126/science.1109987

Thorne A, et al. 1999. "Australia's Oldest Human Remains: Age of the Lake Mungo 3 Skeleton". Journal of Human Evolution 36 (6): 591-612.

Torroni A, et al. 1993. "Asian affinities and Continental Radiation of the Four Founding Native American mtDNAs. American Journal Human Genetics 53: 563-590.

Wade, Nicholas. 1997. "To People the World, Start with 500." The New York Times (Nov. 11): p. F1.

Wade, Nicholas. 2006. Before the Dawn: Recovering the Lost History of Our Ancestors. New York: Penguin.

Walter, Robert. 2000. "Early Human Occupation of the Red Sea Coast of Eritrea during the last Interglacial." Nature, Vol. 405 
(May): 65-69.

Wells, Spencer. 2002. The Journey of Man: A Genetic Odyssey. Princeton; Princeton University Press.

Wells, Spencer. 2006. Deep Ancestry: Inside the Genographic Project. Washington, D.C.: National Geographic.

Wells, H. G. 1920. An Outline of History, Being a Plain History of Life and Mankind. 2 vols. Revised by Raymond Postgate. Garden City, NY: Garden City Books.

Wilken, Uffe, et al. 2016. "Textbook Story of How Humans Populated America is 'Biologically Unviable'." Nature, 10 August. 